\title{
Experimental Investigation and Mathematical Modeling of Microwave Thin Layer Drying Behaviour of Apricot, Kiwi and Mint Leaves
}

\author{
Mehmet ŞíMŞEK ${ }^{1}$, Haydar KÜÇÜK ${ }^{2 *}$, Adnan MíDİLLi $\dot{i}^{3}$ \\ ${ }^{1}$ Malatya 2. Organized Industry Directorate, 2. Organized Industry District, 1. Street, No: 11, 44110 Malatya, Turkey \\ ${ }^{2}$ Department of Mechanical Engineering, Faculty of Engineering and Architecture, Recep Tayyip Erdogan University, \\ 53100 Rize, Turkey \\ ${ }^{3}$ Department of Mechanical Engineering, Faculty of Mechanical Engineering, Y1ldı Technical University, 34349 İstanbul, \\ Turkey

\begin{tabular}{lr}
\hline${ }^{*}$ Sorumlu Yazar/Corresponding Author & Araştırma Makalesi/Research Article \\
E-mail: haydar.kucuk@erdogan.edu.tr & Geliş Tarihi/Received: 13.07.2021 \\
Orcid ID: 0000-0001-6493-4943 & Kabul Tarihi/Accepted: 05.11.2021 \\
\hline
\end{tabular}

\begin{abstract}
In this study, experimental investigation and mathematical modeling of microwave drying behavior of some vegetables and fruits such as apricot, kiwi and mint leaves are performed. In this regard, a microwave oven is used for experiments and 23 thin layer drying curve equation in the literature are evaluated for mathematical modeling of drying behavior of those products. For this purpose, mass loss and drying time are measured depending on six different microwave powers $(100 \mathrm{~W}, 300 \mathrm{~W}, 450 \mathrm{~W}, 600 \mathrm{~W}, 700 \mathrm{~W}$, and $800 \mathrm{~W})$ and dimensionless mass ratio, moisture content, drying rate and mass shrinkage ratio are estimated and variation of colors are observed. For comparison of equations obtained from modeling, 14 different evaluation criteria are used and the best five drying model are determined. Consequently, it is determined that the most suitable microwave powers were $300 \mathrm{~W}, 600 \mathrm{~W}$, 700W and the best drying models are Modified Page, Midilli-Kucuk and Midilli-Kucuk for apricot, kiwi and mint leaves, respectively. Also, it is observed that when the microwave power increases, drying time significantly decreases. However, it is seen that microwave drying method is suitable for drying of kiwi and mint leaves but not suitable for drying of apricot especially at high microwave powers.
\end{abstract}

Keywords: Thin layer drying, Microwave drying, Apricot, Kiwi, Mint leaves, Mathematical modeling

\section{Kayısı, Kivi ve Nane Yapraklarının Mikrodalga İnce Tabaka Kurutma Davranışının Deneysel Olarak İncelenmesi ve Matematiksel Modellenmesi}

\section{ÖZET}

Bu çalışmada kayısı, kivi ve nane yaprağı gibi bazı sebze ve meyvelerin mikrodalga kurutma davranışlarının deneysel olarak incelenmesi ve matematiksel modellemesi yapıldı. Bu bağlamda deneyler için mikrodalga firın kullanıldı ve bu ürünlerin kuruma davranışlarının matematiksel modellemesi için literatürdeki 23 ince tabaka kurutma eğrisi denklemi değerlendirildi. Bu amaçla, altı farklı mikrodalga gücü $(100 \mathrm{~W}, 300 \mathrm{~W}, 450 \mathrm{~W}, 600 \mathrm{~W}$, $700 \mathrm{~W}$ ve $800 \mathrm{~W}$ ) için kütle kaybı ve kuruma süresi ölçüldü ve boyutsuz kütle oranı, nem içeriği, kurutma hızı ve büzülme oranı hesaplandı ve renk değişimleri gözledi. Modellemeden elde edilen denklemlerin karşılaştırılması için 14 farklı değerlendirme kriteri kullanıldı ve en iyi beş kurutma modeli belirlendi. Sonuç olarak en uygun mikrodalga güçlerinin kayısı, kivi ve nane yaprakları için sırasıyla 300W, 600W, 700W ve en iyi kurutma modellerinin sırasıyla Modifiye edilmiş Page, Midilli-Kucuk ve Midilli-Kucuk olduğu belirlendi. Ayrıca, mikrodalga gücü arttığında kuruma süresinin önemli ölçüde azaldığı gözlemlendi. Ancak, mikrodalga kurutma yönteminin kivi ve nane yapraklarının kurutulması için uygun olduğu fakat özellikle yüksek mikrodalga güçlerinde kayısının kurutulması için uygun olmadığı görüldü.

Anahtar Kelimeler: İnce tabaka kurutma, Mikrodalga kurutma, Kayısı, Kivi, Nane yaprakları, Matematik modelleme

\section{Cite as;}

Şimşek, M., Küçük, H., Midilli, A. (2021). Experimental Investigation and Mathematical Modeling of Microwave Thin Layer Drying Behaviour of Apricot, Kiwi and Mint Leaves, Recep Tayyip Erdogan University Journal of Science and Engineering, 2(2), 13-35. Doi: 10.53501/rteufemud.969314 


\section{Introduction}

Drying is an important process that reduces the moisture of the wet product to the desired levels by removing moisture from the product by diffusion and evaporation from the surface, and is widely used in sectors including chemical, agriculture, biotechnology, food, polymer, ceramics, pharmaceutical, pulp and paper, mineral and timber (Kucuk et al., 2014). Moreover, it is one of the cheapest and easiest methods that protect foods from adverse environmental conditions (Midilli et al., 1999), removing moisture from the product, reducing the speed of microbial and biochemical reactions, preserving product quality (Qiu et al., 2019). Decomposition of antioxidants in the high temperature drying process is a significant loss of quality and therefore it is important to apply a lower temperature process (Lopez-Vidana et al., 2017). However, thin layer drying can be defined as the process of removal of moisture from a material by passing of drying air through a thin layer of a product (Inyang et al., 2018).

Reducing the drying time in drying processes is very important for reducing energy costs, and it is observed that drying time is significantly reduced in drying systems where microwave integrated drying techniques are used when compared to conventional drying systems (Yurtsever, 2005; Nindo et al., 2003). Furthermore, it is observed that there is no significant difference between the color of the product in microwave drying and the color of the fresh product, only a slight decrease in color brightness (Gunasekaran, 1999; Yurtsever, 2005). In addition, one of the important parameters affecting the quality of the product during drying is the drying rate that depends on internal and external factors. External factors such as drying velocity and relative humidity of the air and the surface area of the substance are independent (Gunasekaran, 1999; Yurtsever, 2005). On the other hand, internal factors which are permeability, porosity, solubility, thermal conductivity are due to the internal structure of the material (Midilli et al., 1999; Kucuk et al., 2014).
All these factors are very important for all type of drying processes.

Among the drying processes, microwave drying is very important process for vegetables and fruits, and carried out by microwave dryers that are one of the efficient dryers with their features including process control convenience, product selectivity and shortening of drying time. Moreover, compared to conventional methods, the advantage of microwave drying method is that it provides homogeneous heating at every point that absorbs the microwave (Drouzas et al., 1999). In some products where the depth of penetration of microwaves into the product is limited and burning occurs because of energy accumulation at certain points and therefore microwave drying is not suitable for all products (Drouzas et al. 1999; Won et al., 2004).

Volumetric heating is the most important feature of microwave heating. The short start-up time and homogeneous heating provided by the absorption (penetration) of the microwave into the material shorten the process time (Venkatesh and Raghavan, 2004).

Under these important considerations, a comprehensive literature review has been performed and given in Table 1 .

Using the useful theoretical and experimental knowledge in the above studies, an experimental investigation and mathematical modeling of microwave drying behavior of apricot, kiwi and mint leaves has been performed in this study. For this purpose, a microwave oven is used and 23 thin layer drying curve equations are evaluated for selecting the best thin layer drying curve equations in terms of the mathematical modeling, and 14 different evaluation criteria are taken into consideration to determine the appropriate drying curve equations for representing the microwave drying behavior of these products. Considering the above explanations, as a result of the comprehensive literature review, Although it is noticed that there are limited studies on microwave drying and mathematical modeling of 
apricot, kiwi and mint, there is no such a comprehensive study on apricot, kiwi and mint leaves in the literature. Therefore, this is the main motivation behind this work indicating the originality of the paper.
It is expected that this research study will contribute to researchers, investors, policy makers on drying processes of vegetables and fruits in order to determine the microwave drying behavior and conditions of the vegetables and fruits as well as other agricultural products and crops.

Table 1. Literature survey for microwave drying

\begin{tabular}{|c|c|c|c|}
\hline Product & Reference & Product & Reference \\
\hline \multicolumn{4}{|c|}{ Microwave integrated drying process } \\
\hline Kiwifruits & Maskan, 2001 & Mint & Yurtsever, 2005 \\
\hline Dusts & McMinn et al., 2005 & Kocabaş carpan & Duan et al., 2005 \\
\hline Parsley & Soysal et al., 2006 & Lactose powder & McMinn, 2006 \\
\hline Macadamia nuts & Silva et al, 2006 & Saskatoon berry & Reddy, 2006 \\
\hline Spinach & $\begin{array}{l}\text { Dadali et al., 2007; Özkan et } \\
\text { al., 2007, Özbek and Dadali, } \\
2007\end{array}$ & Leek & Dadali and Özbek, 2008 \\
\hline Beef & Thiagarajan, 2008 & Tomato pulp & Al-Harahsheh et al., 2009 \\
\hline Calcium sulfate & Ganesapillai et al., 2009 & $\begin{array}{l}\text { Zizyphus jujuba } \\
\text { Miller }\end{array}$ & Wang et al., 2009 \\
\hline Sugar cane pulp & Shah and Joshi, 2010 & Basil leaves & Demirhan and Özbek, 2010a \\
\hline Purslane & Demirhan and Özbek, 2010b & Gypsum & $\begin{array}{l}\text { Ganesapillai et al., 2008; Pillai et } \\
\text { al., 2010; Ganesapillai et al., } 2011\end{array}$ \\
\hline Coriander leaves & Sarimeseli, 2011 & Celery leaves & $\begin{array}{l}\text { Demirhan and Özbek, 2011; } \\
\text { Karaaslan and Tunçer, } 2011\end{array}$ \\
\hline Rosehip, mulberry & Evin, 2011 & Sliced potato & Darvishi, 2012 \\
\hline Licorice & Balbay and Şahin, 2012 & Ginger & Murthy and Manohar, 2012 \\
\hline Fig & Sharifian et al., 2012 & Sardine fish & Darvishi et al., 2013 \\
\hline Quince & Baltacıŏglu et al., 2015 & $\begin{array}{l}\text { Compressed } \\
\text { Lignite spheres }\end{array}$ & Fu et al., 2017 \\
\hline Oil palm veneer & Lekachaiworakul et al., 2017 & Lignite & Li et al., 2018 \\
\hline Green peas & Chahbani et al., 2018 & Apple slices & Cuccurullo et al., 2019 \\
\hline Low grade manganese ore & Du et al., 2020 & $\begin{array}{l}\text { Germinated brown } \\
\text { rice }\end{array}$ & Shen et al., 2020 \\
\hline Green microalgae & Agbede et al., 2020 & & \\
\hline \multicolumn{4}{|c|}{ Microwave-Convection Drying Process } \\
\hline Powders & McMinn et al., 2005 & Lactose powder & McMinn, 2006 \\
\hline Grape & Bingol et al., 2008 & $\begin{array}{l}\text { Red pepper, } \\
\text { Spinach, tea leaves }\end{array}$ & $\begin{array}{l}\text { Karaaslan, 2008; Karaaslan and } \\
\text { Tuncer, } 2008\end{array}$ \\
\hline Beef & Thiagarajan, 2008 & Dill & Eştürk and Soysal, 2010 \\
\hline Mushrooms & Argyropoulos et al., 2011 & Banana & Ganesapillai et al., 2011 \\
\hline Green tea leaves & Karaaslan and Tunçer, 2011 & Flax fiber & Nair et al., 2011 \\
\hline Wheat & Hemis et al., 2011 & Soybean & Ranjbaran and Zare, 2012 \\
\hline Sage leaves & Esturk, 2012 & Vine leaf & Alibaş, 2012 \\
\hline $\begin{array}{l}\text { Basil, mint, oregano, } \\
\text { celamine, parsley, arugula }\end{array}$ & $\begin{array}{l}\text { Sledz and Witrowa-Rajchert, } \\
2012\end{array}$ & Apple slices & Zarein et al., 2015 \\
\hline Chamomile leaves & Motevali et al., 2016 & Strawberries & Szadzinska et al., 2016 \\
\hline Carrot & $\begin{array}{l}\text { Xu et al., 2020; Cuccurullo et } \\
\text { al, } 2019\end{array}$ & & \\
\hline
\end{tabular}




\section{Materials and Methods}

In this part of the paper, material and method are presented. In material section, the raw materials used for drying and experimental system have been introduced in detail. In method section, microwave drying process has been defined in detail.

\subsection{Material}

For the microwave drying experiments, Apricot (Prunus armeniaca), kiwi (Actinidia) and mint (Mentha) are used in drying experiments. Apricot, known as Levent type, is taken from Levent hamlet of Akçadağ district of Malatya, Turkey. Kiwi is taken from kiwifruit offered for consumption in the market. Mint is collected from fresh shoots from the garden. In the experiments, fresh apricots of $150 \mathrm{~g}$, kiwi of $85 \mathrm{~g}$ and mint of $50 \mathrm{~g}$ are put on a porcelain plate with $1-2 \mathrm{~mm}$ diameter hole and placed on the turntable of the microwave oven. Depending on the microwave power, weight loss is measured at periodic time intervals with precision scales. The drying process continued until the natural looking drying cycle of the product. Levent type apricot, kiwi and mint samples used in the study are shown in Figure 1.

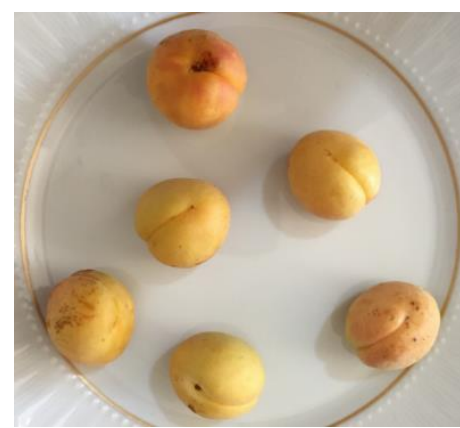

(a)

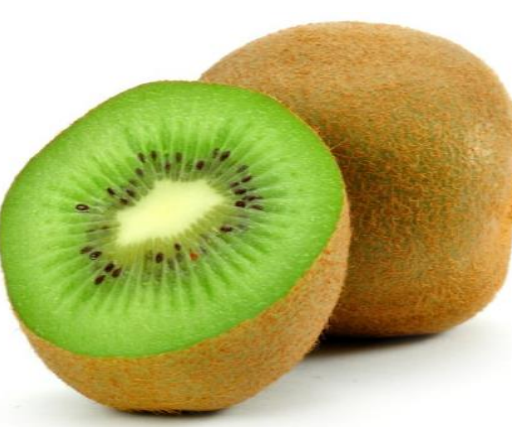

(b)

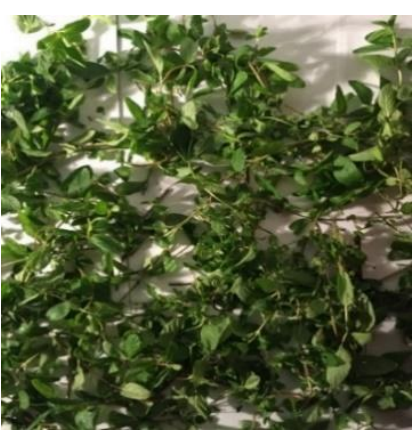

(c)

Figure 1. (a) Levent type apricot, (b) Kiwi, (c) Mint (Şimşek, 2018)

\subsection{Method}

Microwave drying experiments is carried out using a Samsung brand ME711K microwave oven, which can operate at a total power level of 6, including 100W, 300W, 450W, 600W, 700W and 800W (Figure-2a). Fakir brand Molly Digital Kitchen Scale is used to measure the weight with a sensitivity of 1g (Figure-2b). Loyka BT 3000, which has a temperature measurement range of $50 / 70 \mathrm{C}( \pm 1 \mathrm{C})$ and a humidity measurement range of $10 \%-95 \%( \pm 5 \%)$, is used in the measurement of ambient temperature and humidity (Figure-2c). DFA California moisture analyzer is used for moisture determination before and after drying apricot (Figure-2d). Caliper is used in kiwi thickness measurement (Figure-2e).

\subsection{Mathematical Modeling}

Examining the drying process and determining the drying times of moist products are considered as two important areas for drying. Kucuk et al. (2014) perform a comparative analysis of 67 models under 28 performance evaluation criteria.
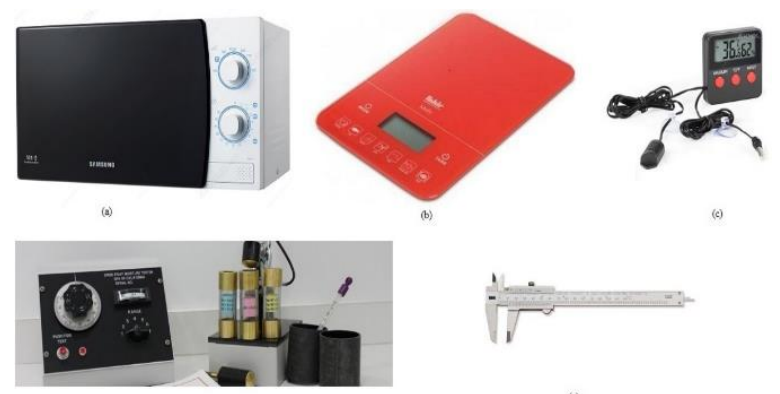

Figure 2. Devices (a) Microwave oven, (b) Balance, (c) Thermometer - Humidity measurement, (d) DFA California moisture measurement, (e) Caliper (Şimşek, 2018)

\subsubsection{Drying Curve Equations}

The 23 mathematical modeling equations are selected from the literature (Kucuk et al., 2014) and given in Table 2. 
Table 2. Thin-layer drying-curve equations

\begin{tabular}{|c|c|c|c|}
\hline No & Model name & Model equation & Eq. No \\
\hline$\overline{1}$ & $\begin{array}{l}\text { Newton (Lewis, Exponential, Single } \\
\text { exponential) }\end{array}$ & $M R=\exp (-k t)$ & (1) \\
\hline 2 & Page & $M R=\exp \left(-k t^{n}\right)$ & (2) \\
\hline 3 & Modified Page & $M R=\exp \left(-(k t)^{n}\right)$ & (3) \\
\hline 4 & Modified Page-I & $M R=\exp \left((-k t)^{n}\right)$ & (4) \\
\hline 5 & Modified Page-II & $M R=\exp \left(-c\left(\frac{t}{L^{2}}\right)^{n}\right)$ & (5) \\
\hline 6 & Henderson and Pabis (Single term) & $M R=a \exp (-k t)$ & (6) \\
\hline 7 & $\begin{array}{l}\text { Logarithmic (Asymptotic) Yagcioglu } \\
\text { et al. }\end{array}$ & $M R=a \exp (-k t)+c$ & (7) \\
\hline 8 & Midilli-Kucuk (Midilli, Midilli et al.) & $M R=a \exp \left(-k t^{n}\right)+b t$ & (8) \\
\hline 9 & Demir et al. & $M R=a \exp (-k t)^{n}+b$ & (9) \\
\hline 10 & Two-Term & $M R=a \exp \left(-k_{0} t\right)+b \exp \left(-k_{1} t\right)$ & (10) \\
\hline 11 & Two-Term Exponential & $M R=a \exp (-k t)+(1-a) \exp (-k a t)$ & (11) \\
\hline 12 & $\begin{array}{l}\text { Verma et al. (Modified Two-Term } \\
\text { Exponential) }\end{array}$ & $M R=a \exp (-k t)+(1-a) \exp (-g t)$ & (12) \\
\hline 13 & $\begin{array}{l}\text { Approximation of Diffusion } \\
\text { (Diffusion approach) }\end{array}$ & $M R=a \exp (-k t)+(1-a) \exp (-k b t)$ & (13) \\
\hline 14 & $\begin{array}{l}\text { Modified Henderson and Pabis } \\
\text { (Three Term Exponential) }\end{array}$ & $M R=a \exp (-k t)+b \exp (-g t)+c \exp (-h t)$ & (14) \\
\hline 15 & Thompson & $t=a \ln (M R)+b(\ln (M R))^{2}$ & (15) \\
\hline 16 & Wang and Singh & $M R=1+a t+b t^{2}$ & (16) \\
\hline 17 & Hii et al. & $M R=a \exp \left(-k t^{n}\right)+c \exp \left(-g t^{n}\right)$ & (17) \\
\hline 18 & Simplified Fick’s diffusion (SFFD) & & (18) \\
\hline 19 & Weibull & $M R=\exp \left(-\left(\frac{t}{a}\right)^{b}\right)$ & (19) \\
\hline 20 & Aghbashlo et al. & $M R=\exp \left(-\frac{k_{1} t}{1+k_{2} t}\right)$ & $(20)$ \\
\hline 21 & Parabolic & $M R=a+b t+c t^{2}$ & $(21)$ \\
\hline 22 & Balbay and Şahin & $M R=(1-a) \exp \left(-k t^{n}\right)+b$ & $(22)$ \\
\hline 23 & Alibas (Modified Midilli-Kucuk) & $M_{R}=a \exp \left(-k t^{n}\right)+b t+g$ & (23) \\
\hline
\end{tabular}

\subsubsection{Evaluation Criteria}

The most used evaluation criteria in the literature for thin layer and thin layer drying models are coefficient of determination, reduced chi-square, root mean square error, mean relative percentage error, standard error of estimate, mean bias error and reduced sum square error, respectively. The 14 evaluation criteria of thin-layer drying curveequations are selected and used in the light of review paper by Kucuk et al. (2014) and given in Table 3. 
Table 3. Evaluation criteria of thin-layer drying curve-equations

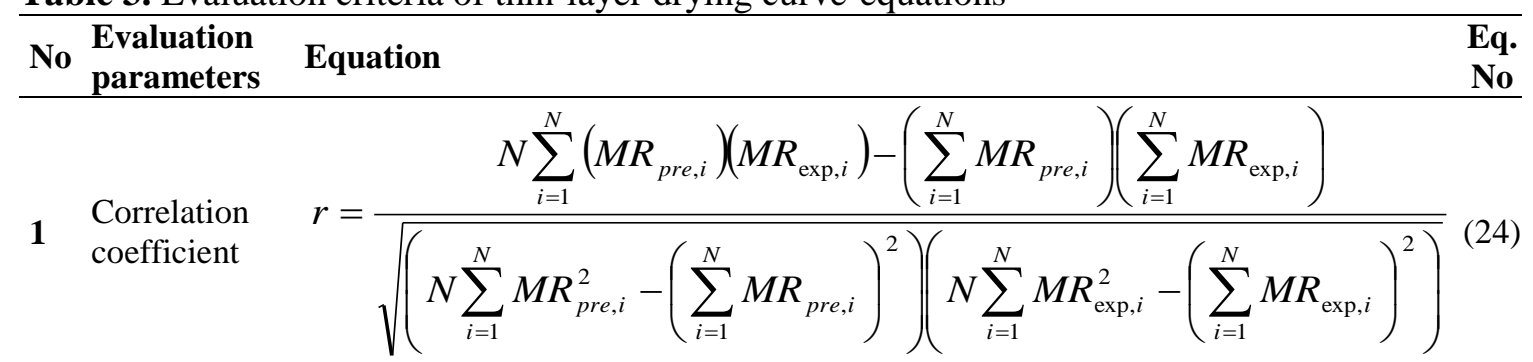

$2 \begin{aligned} & \text { Total sum of } \\ & \text { squares }\end{aligned} S T=\sum_{1}^{n}\left(M R_{\text {exp }, i}-M R_{\text {avg }}\right)^{2}$

Error

$3 \begin{aligned} & \text { (residual) } \\ & \text { sum }\end{aligned}$ of $S S E=\sum_{i=1}^{N}\left(M R_{\mathrm{exp}, i}-M R_{p r e, i}\right)^{2}$

squares

$4 \begin{aligned} & \text { Residual sum } \\ & \text { of squares }\end{aligned} R S S=\sum_{i=1}^{N}\left(M R_{\text {exp }, i}-M R_{p r e, i}\right)^{2}$

$5 \begin{gathered}\text { Coefficient of } \\ \text { determination }\end{gathered} R^{2}=\frac{S S R}{S S T}=1-\frac{S S E}{S S T}$

6 Adjusted $\mathrm{R}^{2} \quad \bar{R}^{2}=1-\left(1-R^{2}\right) \frac{N-1}{N-k-1}$

$7 \begin{aligned} & \text { Reduced chi- } \\ & \text { square }\end{aligned} \chi^{2}=\frac{\sum_{i=1}^{N}\left(M R_{\text {exp }, i}-M R_{p r e, i}\right)^{2}}{N-n}$

$8 \begin{aligned} & \text { Root mean } \\ & \text { square error }\end{aligned} R M S E=\sqrt{\frac{\sum_{i=1}^{N}\left(M R_{p r e, i}-M R_{\text {exp }, i}\right)^{2}}{N}}$

9 Residuals residuals $=\sum_{i=1}^{N}\left(M R_{\mathrm{exp}, i}-M R_{\text {pre }, i}\right)$

10 efficiency

$$
E F=\frac{\sum_{i=1}^{N}\left(M R_{\exp , i}-M R_{\exp , a v e}\right)^{2}-\sum_{i=1}^{N}\left(M R_{p r e, i}-M R_{\exp , i}\right)^{2}}{\sum_{i=1}^{N}\left(M R_{\text {exp }, i}-M R_{\text {exp }, a v e}\right)^{2}}
$$

$11 \begin{aligned} & \begin{array}{l}\text { Standard error } \\ \text { of estimate }\end{array} \\ & \text { S }\end{aligned}$

$12 \begin{aligned} & \text { Reduced sum } \\ & \text { square error }\end{aligned} \quad R S S E=\frac{\sum_{i=1}^{N}\left(M R_{\text {exp }, i}-M R_{c a l, i}\right)^{2}}{N}$

13 Mean bias error $\quad M B E=\frac{\sum_{i=1}^{N}\left(M R_{p r e, i}-M R_{\mathrm{exp}, i}\right)}{N}$

$14 \begin{aligned} & \text { Mean relative } \\ & \text { percentage error }\end{aligned} P=\frac{100}{N} \sum_{i=1}^{N} \frac{\left|M R_{\text {exp }, i}-M R_{p r e, i}\right|}{M R_{\text {exp }, i}}$ 


\subsubsection{Basic Drying Calculations}

Dimensionless mass ratio, moisture content, mass shrinkage ratio and drying rate are described in Equations (38), (39), (40) and (41), respectively, (Midilli et al., 1999; Alibaş, 2012).

Dimensionless mass ratio

$$
M R=\frac{M_{t}-M_{e}}{M_{i}-M_{e}}
$$

Moisture content

$$
M C(\%)=\frac{M_{t}-M_{e}}{M_{i}}
$$

Mass shrinkage ratio

$$
S_{m r}=\frac{M_{t}}{M_{i}}
$$

Drying rate

$$
D R=-\frac{d M}{d t}=-\frac{M_{t+d t}-M_{t}}{d t}
$$

\subsubsection{Experimental Errors and Uncertainty Analysis}

In experimental studies, the accuracy of the measured values is as important as the results. The most important variable affecting accuracy is errors that may arise due to different reasons during the experimental. These errors can occur in two different ways. One of them is the errors caused by the structure of the experiment set and the measurement tools and the other is the errors caused by the operator. Errors and uncertainties in experiments may occure some variables such as device selection, environmental impact, observation, reading data, and test planning (Midilli et al., 1999; Doğru et al., 2002).

Total error rate in a measurement with $\mathrm{n}$ independent variables:

$$
\begin{aligned}
& W_{R}=\left[\left(\frac{\partial R}{\partial x_{1}} w_{1}\right)^{2}+\left(\frac{\partial R}{\partial x_{2}} w_{2}\right)^{2}+\left(\frac{\partial R}{\partial x_{3}} w_{3}\right)^{2}+\right. \\
& \left.\cdots+\left(\frac{\partial R}{\partial x_{n}} w_{n}\right)^{2}\right]^{1 / 2}
\end{aligned}
$$

or

$$
\begin{aligned}
& \frac{W_{R}}{R}=\left[\left(\frac{w_{1}}{x_{1}}\right)^{2}+\left(\frac{w_{2}}{x_{2}}\right)^{2}+\left(\frac{w_{3}}{x_{3}}\right)^{2}+\cdots+\right. \\
& \left.\left(\frac{w_{n}}{x_{n}}\right)^{2}\right]^{1 / 2}
\end{aligned}
$$

$\left(a_{1}\right)$ Error due to mass, power and time measurements during experiments $= \pm 1 \mathrm{~g}$, $\pm 0,5 \mathrm{~W}, \pm 0.001 \mathrm{~min}$.

$\left(a_{2}\right)$ Error caused by reading of mass, power and time $= \pm 0.01 \mathrm{~g}, \pm 0.005 \mathrm{~W}, \pm 0.00001 \mathrm{~min}$.

$W_{R}=\left[\left(a_{1}\right)^{2}+\left(a_{2}\right)^{2}+. .\right]^{1 / 2}=\% 1.5$

\section{Results and Discussion}

\subsection{Apricot Samples}

Drying experiments of apricot are performed at $100 \mathrm{~W}, 300 \mathrm{~W}, 450 \mathrm{~W}, 600 \mathrm{~W}, 700 \mathrm{~W}$ and $800 \mathrm{~W}$ microwave powers. The dimensionless mass ratios obtained by using 23 thin or thin layer drying curve equations are estimated for each experiment and the five best model obtained depending on 14 evaluation criteria are given in Figure 3. Also, drying curve equations for $300 \mathrm{~W}$ microwave power for which the most suitable drying is obtained for apricots are evaluated based on 14 evaluation criteria and the results are presented in Table 4. During the determination of the best suitable model when any of correlation coefficient $(r)$, coefficient of determination $\left(R^{2}\right)$, adjusted $\mathrm{R}^{2}$ and modeling efficiency $(\mathrm{EF})$ are higher than 1 for each experiment, these models are not taken into consideration.

The best models are obtained as Wibull, Modified Page, Aghbashlo et al., Aghbashlo et al., Aghbashlo et al., and Modified Page II for 100W, $300 \mathrm{~W}, 450 \mathrm{~W}, 600 \mathrm{~W}, 700 \mathrm{~W}$ and $800 \mathrm{~W}$, respectively, and drying curve equations are given in Equations (45-51) for each best model.

$$
\begin{aligned}
& M R=\exp \left(-\left(\frac{t}{81.86}\right)^{2.007}\right) \\
& M R=\exp \left(-(0.693 t)^{1.875}\right)
\end{aligned}
$$




$$
\begin{aligned}
& M R=\exp \left(-\frac{0.043543 t}{1-0.038517 t}\right) \\
& M R=\exp \left(-\frac{0.061575 t}{1-0.050239}\right) \\
& M R=\exp \left(-\frac{0.06215 t}{1-0.070597 t}\right) \\
& M R=\exp \left(-1.4706\left(\frac{t}{-2.2137^{2}}\right)^{1.9751}\right)
\end{aligned}
$$
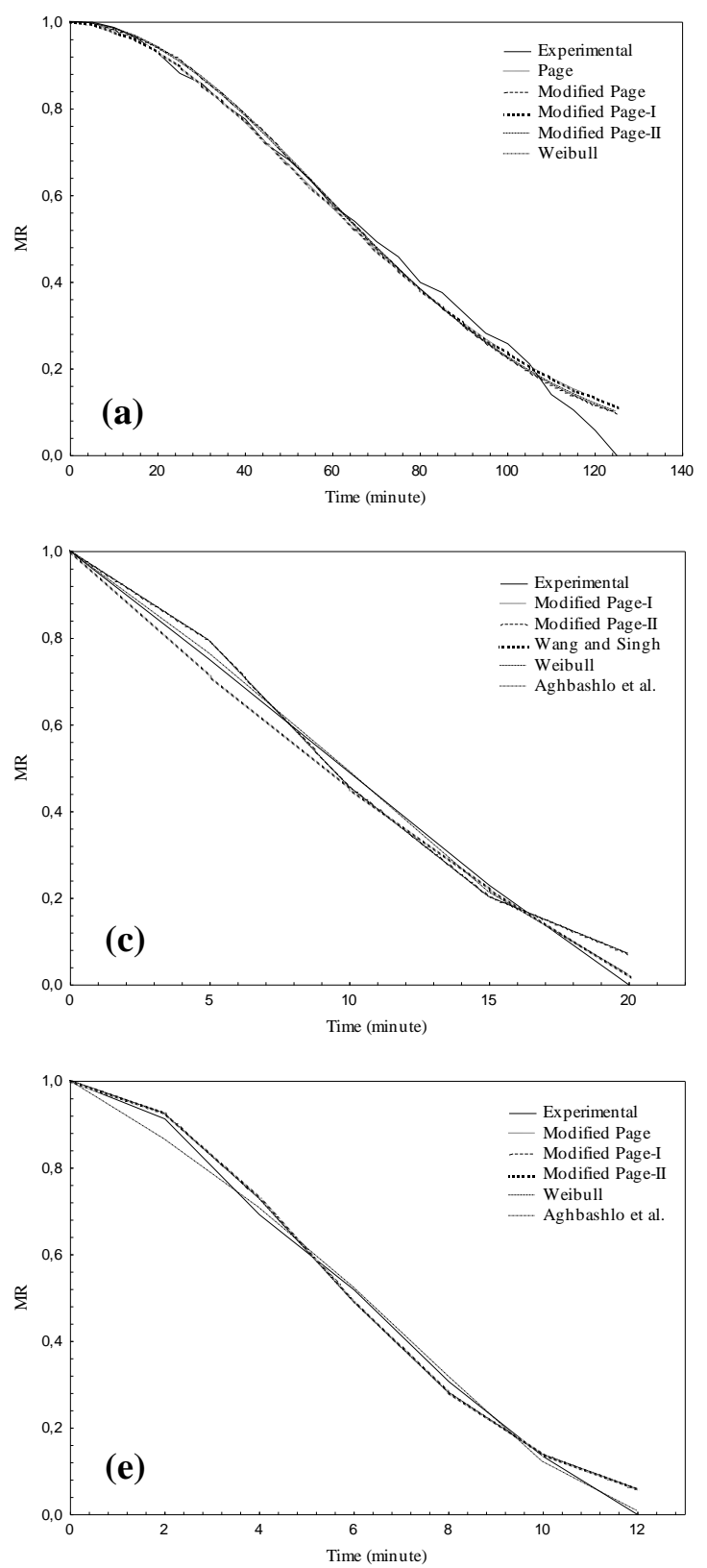

$M R=\exp \left(-\left(\frac{t}{4.0311}\right)^{1.9751}\right)$

Drying experiments of apricot are performed for $800 \mathrm{~W}, 700 \mathrm{~W}, 600 \mathrm{~W}, 450 \mathrm{~W}, 300 \mathrm{~W}$ and $100 \mathrm{~W}$ microwave powers. As seen in Figure 3, drying times are determined as 7, 12, 19, 20, 25 and 125 minutes for $800 \mathrm{~W}, 700 \mathrm{~W}, 600 \mathrm{~W}, 450 \mathrm{~W}, 300 \mathrm{~W}$ and $100 \mathrm{~W}$ power values, respectively. It is seen that the dimensionless mass ratio almost linearly decreases with increasing of time.
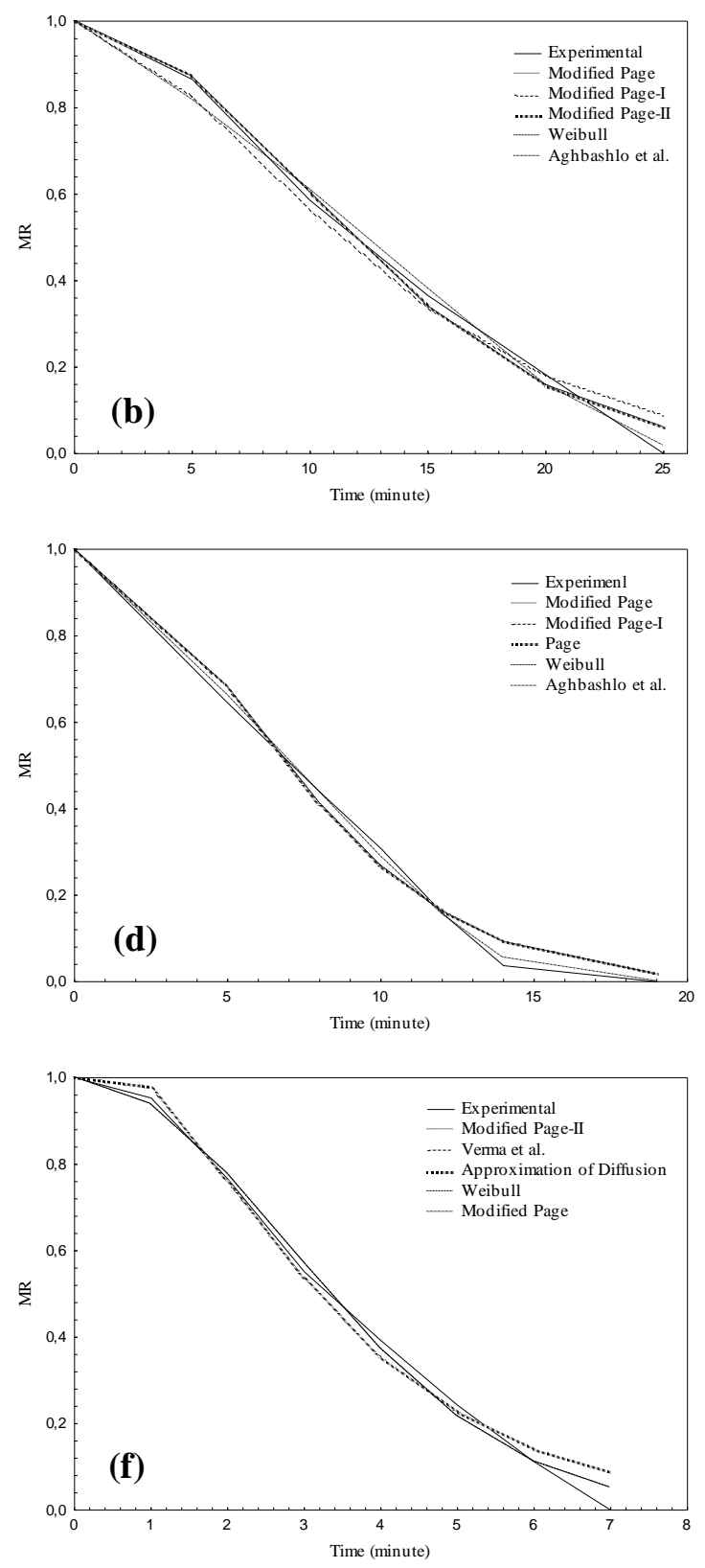

Figure 3. Variation of dimensionless mass ratio over time for apricot (a) $100 \mathrm{~W}$, (b) $300 \mathrm{~W}$, (c) $450 \mathrm{~W}$, (d) $450 \mathrm{~W}$, (e) $600 \mathrm{~W}$, (f) $700 \mathrm{~W}$, (g) $800 \mathrm{~W}$ 
Table 4. Evaluation criteria of apricot for 300W

\begin{tabular}{|c|c|c|c|c|c|c|c|c|c|c|c|}
\hline Model Name & RSS & SST & SSE & $\mathbf{R 2}$ & $\bar{R}^{2}$ & RMSE & residuals & SEE & RSSE & MBE & $\mathbf{P}$ \\
\hline Newton, Lewis & 0.969230 .06836 & 1.56921 & 10.06836 & 0.956440 .01367 & 0.94555 & 0.10674 & 0.02412 & 0.956440 .01367 & 0.01139 & 0.00402 & 2.79153 \\
\hline Page & 0.994950 .01074 & 1.56921 & 10.01074 & 0.993150 .00269 & 0.98859 & 0.04231 & 0.00999 & 0.993150 .00269 & 0.00179 & 0.00166 & 1.02466 \\
\hline Modified Page & 0.996710 .00532 & 1.56921 & 10.00532 & 0.996610 .00133 & 0.99435 & 0.02977 & -0.03440 & 0.996610 .00133 & 0.00089 & 0.00573 & 0.75437 \\
\hline Modified Page-I & 0.994950 .01074 & 1.56921 & 10.01074 & 0.993150 .00269 & 0.98859 & 0.04231 & 0.00999 & 0.993150 .00269 & 0.00179 & 0.00166 & 1.02466 \\
\hline Modified Page-II & 0.996710 .00532 & 1.569 & 10.00532 & 0.996610 .00177 & 0.99153 & 0.02977 & -0.03440 & 0.996610 .00177 & 0.00089 & 0.00573 & 0.75436 \\
\hline Henderson and Pabis & 0.964330 .05827 & 1.569 & 10.05827 & 0.962870 .01457 & 0.93811 & 0.09855 & -0.09143 & 0.962870 .01457 & 0.00971 & 0.01524 & 2.89676 \\
\hline Logarithmic & 0.996870 .00475 & 1.569 & 10.00475 & 0.996970 .00158 & 0.99243 & 0.02813 & -0.00112 & 0.996970 .00158 & 0.00079 & 0.00019 & 0.73500 \\
\hline Midilli-Kucuk & 0.997110 .00447 & 1.56921 & 10.00447 & 0.997150 .00223 & 0.98576 & 0.02729 & -0.01046 & 0.997150 .00223 & 0.00074 & t 0.00174 & 0.77280 \\
\hline Demir et al. & 0.996870 .00474 & 1.56921 & 10.00474 & 0.996980 .00237 & 0.98489 & 0.02811 & 0.00000 & 0.996980 .00237 & 0.00079 & 0.00000 & 0.74599 \\
\hline Two-Term & 0.996870 .00475 & 1.56921 & 10.00475 & 0.996970 .00237 & 0.98487 & 0.02814 & -0.00091 & 0.996970 .00237 & 0.00079 & 0.00015 & 0.74651 \\
\hline Two-Term Exponential & 0.992920 .01219 & 1.56921 & 10.01219 & 0.992230 .00305 & 0.98705 & 0.04508 & -0.05462 & 0.992230 .00305 & 0.00203 & 30.00910 & 1.01170 \\
\hline Verma et al. & 0.994030 .01012 & 1.56921 & 10.01012 & 0.993550 .00337 & 0.98387 & 0.04108 & -0.05018 & 0.993550 .00337 & 0.00169 & 0.00836 & 0.93191 \\
\hline Approximation of Diffusion & 0.994050 .01012 & 1.56921 & 10.01012 & 0.993550 .00337 & 0.98388 & 0.04107 & -0.05057 & 0.993550 .00337 & 0.00169 & 0.00843 & 0.92940 \\
\hline Modified Henderson and Pabis & 0.949130 .05827 & 1.44619 & 90.05827 & $0.95971-0.05827$ & 1.08058 & 0.10795 & -0.09143 & $0.95971-0.05827$ & 0.01165 & 0.01829 & 3.47611 \\
\hline \multicolumn{12}{|l|}{ Thompson } \\
\hline Wang and Singh & 0.005761 .44619 & 0.00576 & 60.99601 & 0.001920 .99203 & 0.03396 & 0.04655 & 0.99601 & 0.001920 .00115 & 0.00931 & 0.77270 & 0.00576 \\
\hline Hii et al. & 0.995060 .00527 & 1.44619 & 90.00527 & 0.99636 & 1.01457 & 0.03246 & -0.02624 & 0.99636 & 0.00105 & 0.00525 & 0.93579 \\
\hline Simplified Fick's diffusion (SFFD) & 0.949130 .05827 & 1.44619 & 90.05827 & 0.959710 .02913 & 0.83883 & 0.10795 & -0.09143 & 0.959710 .02913 & 0.01165 & 0.01829 & 3.47611 \\
\hline Weibull & 0.994910 .00532 & 1.44619 & 90.00532 & 0.996320 .00177 & 0.99264 & 0.03261 & -0.03440 & 0.996320 .00177 & 0.00106 & 0.00688 & 0.90525 \\
\hline Aghbashlo et al. & 0.996110 .00401 & 1.44619 & 90.00401 & 0.997230 .00134 & 0.99446 & 0.02831 & 0.01240 & 0.997230 .00134 & 0.00080 & 0.00248 & 0.86609 \\
\hline Parabolic & 0.987050 .01232 & 1.44619 & 90.01232 & 0.991480 .00616 & 0.96593 & 0.04964 & -0.00348 & 0.991480 .00616 & 0.00246 & 0.00070 & 1.72640 \\
\hline Balbay and Şahin & 0.998690 .00120 & 1.44619 & 90.00120 & 0.999170 .00120 & - & 0.01550 & -0.00001 & 0.999170 .00120 & 0.00024 & +0.00000 & 0.49048 \\
\hline Alibas (Modified Midilli-Kucuk) & 0.994830 .00481 & 1.44619 & 90.00481 & 0.99668 & 1.01329 & 0.03101 & 0.00006 & 0.99668 & 0.00096 & 50.00001 & 0.93612 \\
\hline
\end{tabular}




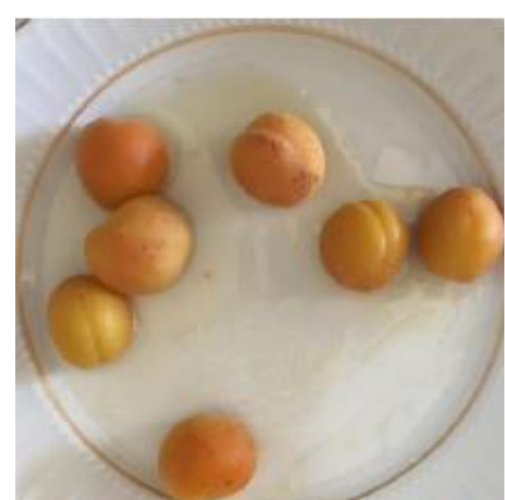

(a)

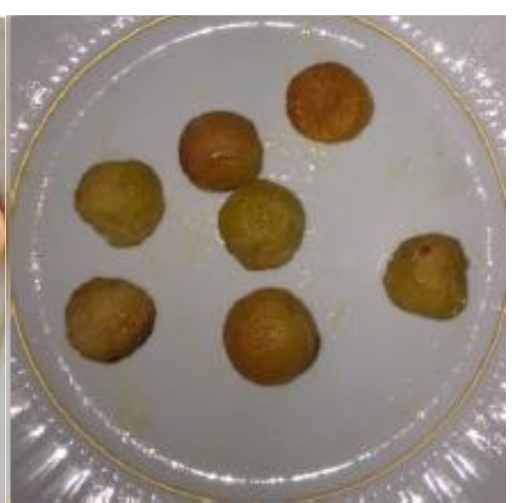

(b)

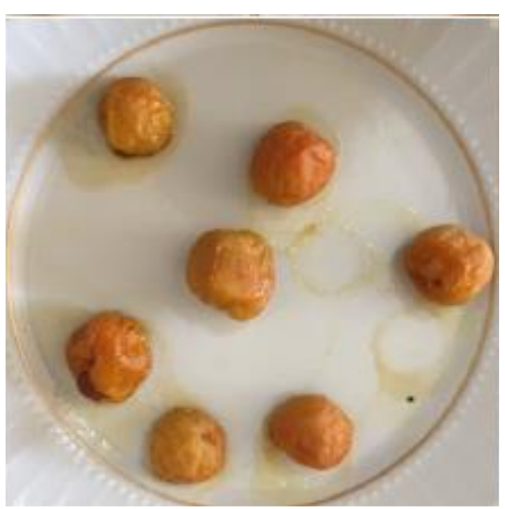

(c)

Figure 4. Photographs of apricot during drying (a) initial stage, (b) mid stage, (c) last stage (Şimşek, 2018)

At $800 \mathrm{~W}, 700 \mathrm{~W}$ and $600 \mathrm{~W}$ microwave powers, slight wrinkling and shape change occur on the outer part of the product during the initial stage of drying. It is observed that the apricot inner center began to burn perceptibly in the following stage. While the wrinkling and shape change on the outer surface continued, bruises in apricot-colored began to appear. In the last stage of drying, while the burning situation starting from the inner center increases, on the outer surfaces, burns occur on the adjacent inner surfaces of apricot in the dish and signs of charring are observed. In these microwave powers, while the product is drying in a short time it is observed that the burning occurred had a negative effect on the product quality.

At $450 \mathrm{~W}$ and $300 \mathrm{~W}$ power values, a stable and slight shape change and wrinkling is observed in the product in the initial stage of drying. However, at $100 \mathrm{~W}$ microwave power, it is observed that there is little loss of mass in the product, the product is stable and there is no change in freshness (see Figure 4a). In the following stage, the drying starting from the inner center of the apricot steadily continues towards the outer surface of the product. While the wrinkling and shape change on the outer surface continue, bruises in apricot-colored appear (see Figure 4b). In the last stage of drying, the drying starting from the inner center is completed with the change of shape and color towards the outer wall (see Figure $4 c)$. While the product is stable and preserving substance specificity no burning is observed (see Figure 4). The drying time of the product increases, natural appearance and color change is observed in the product (see Figure 4). It was observed that the drying performed at $450 \mathrm{~W}$, $300 \mathrm{~W}$ and 100W powers has a positive effect on the product quality compared to the drying at $800 \mathrm{~W}, 700 \mathrm{~W}$ and $600 \mathrm{~W}$ powers.

Apricot is adversely affected by microwave drying process due to its chemical structure containing high sugar. If microwave drying is performed, it should be determined whether the product is suitable for microwave drying or not by examining the dielectric loss factor (Wang et al., 2003). In the microwave drying method, uniform heating is provided at each point product that absorbs the microwave, while in other drying methods, the heat is transferred from the outside to the inside. Also, since all of the energy given is used in drying the product, it is efficient. In addition, not all products are suitable for microwave drying, since the depth of microwave penetration into the product is limited and some products burn as a result of energy accumulation at certain points (Drouzas et al., 1999; Won et al., 2004). Despite the increased evaporation, all the moisture cannot pass through the apricot peel and is kept inside, causing the product to be cooked or scalded or even burned at high powers.

\subsection{Kiwi Samples}

Drying experiments of kiwi are performed at $100 \mathrm{~W}, 300 \mathrm{~W}, 450 \mathrm{~W}, 600 \mathrm{~W}, 700 \mathrm{~W}$ and $800 \mathrm{~W}$ microwave powers. The dimensionless mass ratios determined for the five best model are 
presented in Figure 5. Also, drying curve equations for $600 \mathrm{~W}$ microwave power for which the most suitable drying is obtained for kiwi are presented in Table 5.

Drying times are determined as $7,12,13,22,30$ and 110 minutes for $800 \mathrm{~W}, 700 \mathrm{~W}, 600 \mathrm{~W}, 450 \mathrm{~W}$, $300 \mathrm{~W}$ and $100 \mathrm{~W}$ power values, respectively. It is seen that the dimensionless mass ratio almost linearly decreases with increasing of time.
The best models are obtained as Alibaş (Modified Midilli-Kucuk), Aghbashlo et al., Midilli-Kucuk, Midilli-Kucuk, Alibaş (Modified MidilliKucuk), and Modified Page for 100W, 300W, $450 \mathrm{~W}, 600 \mathrm{~W}, 700 \mathrm{~W}$ and $800 \mathrm{~W}$, respectively, and drying curve equations are given in Equations (52-57) for each best model.

$$
\begin{aligned}
& M R=0.27811 \exp \left(-0.0018 t^{2.18479}\right)-0.00656+0.71709 \\
& M R=\exp \left(-\frac{0.02841 t}{1-0.02630 t}\right) \\
& M R=0.99986 \exp \left(0.05861 t^{0.0000008}\right)-0.049716 \\
& M R=0.98466 \exp \left(0.003166^{1.18693}\right)-0.077114 t \\
& M R=4.76926 \exp \left(-0.35410^{1.178834}\right)+0.108842 t-3.76936 \\
& M R=\exp \left(-(0.25485 t)^{1.77583}\right)
\end{aligned}
$$

There is no noticeable change in the product in the initial stage of the drying process for $800 \mathrm{~W}$, $700 \mathrm{~W}$ microwave power values. In the following stage, it is observed that color change occure in the kiwi sample and redness determine in the core part of the product center. In the last stage of drying, the shape and color change in the product gradually increased, and burning on the inner surfaces and firing towards the outer Wall occur. While drying is observed in the product in a short time, it was observed that the burning occurred had a negative effect on the product quality.

In the initial stage at $600 \mathrm{~W}, 450 \mathrm{~W}, 300 \mathrm{~W}, 100 \mathrm{~W}$ microwave power values, wrinkling and a little shape and color occurred in the product (see Figure 6a).
In the following drying stage, it is seen that redness observed in the core part of the middle part of the product and color and shape change occur in the kiwi samples (see Figure 6b). In the last drying stage, the shape and color change in the product gradually increased and redness occurred on the inner surfaces (see Figure 6c). It is observed that the product tends to dry naturally. The fact that the structure of the inner core part of the kiwi samples is different from the other parts has a negative effect on the drying of the product. While rednesses and even burns are observed in the central part of the samples, it is determined that the drying showed different characteristics as it moved away from the center and non-uniform drying occur. 

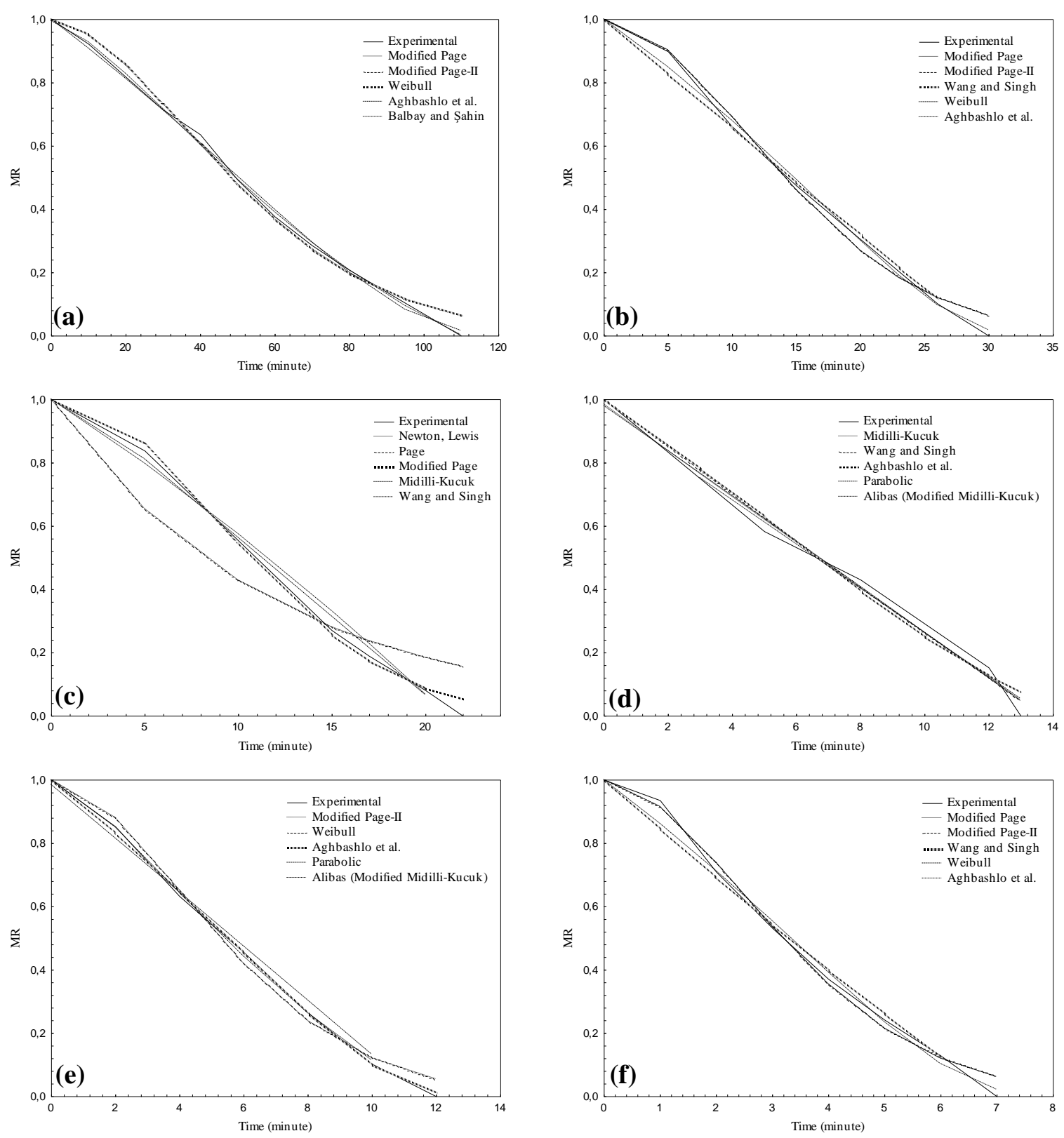

Figure 5. Variation of dimensionless mass ratio over time for kiwi (a) 100W, (b) 300W, (c) 450W, (d) $450 \mathrm{~W}$, (e) $600 \mathrm{~W}$, (f) $700 \mathrm{~W}$, (g) $800 \mathrm{~W}$ 
Table 5. Evaluation criteria of kiwi for $600 \mathrm{~W}$

\begin{tabular}{|c|c|c|c|c|c|c|c|c|c|c|c|c|c|c|}
\hline Model Name & $\mathbf{r}$ & RSS & SST & SSE & $\mathbf{R 2}$ & $\chi^{2}$ & $\bar{R}^{2}$ & RMSE & residuals & EF & SEE & RSSE & MBE & $\mathbf{P}$ \\
\hline Newton Lewis & 0.97014 & 0.05272 & 1.61380 & 0.05272 & 0.96733 & 0.00879 & 0.96080 & 0.08679 & -0.00822 & 0.96733 & 0.00879 & 0.00753 & 0.00117 & 2.10817 \\
\hline Page & 0.97014 & 0.05272 & 1.61380 & 0.05272 & 0.96733 & 0.01054 & 0.95099 & 0.08679 & -0.00822 & 0.96733 & 0.01054 & 0.00753 & 0.00117 & 2.10817 \\
\hline Modifiye Page & 0.98351 & 0.02426 & 1.61380 & 0.02426 & 0.98497 & 0.00485 & 0.97745 & 0.05887 & -0.05759 & 0.98497 & 0.00485 & 0.00347 & 0.00823 & 1.36552 \\
\hline Modifiye Page-I & 1.23245 & 2.77990 & 1.61380 & 2.77990 & -0.72258 & 0.55598 & -1.58386 & 0.63018 & -3.79167 & -0.72258 & 0.55598 & 0.39713 & 0.54167 & 16.88312 \\
\hline Modifiye Page-II & 0.98351 & 0.02426 & 1.61380 & 0.02426 & 0.98497 & 0.00606 & 0.96994 & 0.05887 & -0.05759 & 0.98497 & 0.00606 & 0.00347 & 0.00823 & 1.36551 \\
\hline Henderson and Pabis & 0.96764 & 0.04906 & 1.61380 & 0.04906 & 0.96960 & 0.00981 & 0.95440 & 0.08372 & -0.07477 & 0.96960 & 0.00981 & 0.00701 & 0.01068 & 2.17362 \\
\hline Logarithmic & 0.99516 & 0.00701 & 1.61380 & 0.00701 & 0.99566 & 0.00175 & 0.99132 & 0.03164 & -0.00230 & 0.99566 & 0.00175 & 0.00100 & 0.00033 & 0.90818 \\
\hline Midilli-Kucuk & 0.99529 & 0.00683 & 1.61380 & 0.00683 & 0.99577 & 0.00228 & 0.98730 & 0.03124 & -0.00001 & 0.99577 & 0.00228 & 0.00098 & 0.00000 & 0.90645 \\
\hline Demir et al. & 0.99020 & 0.01423 & 1.61380 & 0.01423 & 0.99118 & 0.00474 & 0.97355 & 0.04508 & -0.00294 & 0.99118 & 0.00474 & 0.00203 & 0.00042 & 1.01982 \\
\hline Two-Term & 0.96764 & 0.04906 & 1.61380 & 0.04906 & 0.96960 & 0.01635 & 0.90880 & 0.08372 & -0.07478 & 0.96960 & 0.01635 & 0.00701 & 0.01068 & 2.17362 \\
\hline Two-Term Exponential & 0.98087 & 0.02855 & 1.61380 & 0.02855 & 0.98231 & 0.00571 & 0.97346 & 0.06387 & -0.05337 & 0.98231 & 0.00571 & 0.00408 & 0.00762 & 1.37354 \\
\hline Verma et al. & 0.98178 & 0.02708 & 1.61380 & 0.02708 & 0.98322 & 0.00677 & 0.96644 & 0.06219 & -0.05278 & 0.98322 & 0.00677 & 0.00387 & 0.00754 & 1.35907 \\
\hline Approximation of Diffusion & 0.98178 & 0.02708 & 1.61380 & 0.02708 & 0.98322 & 0.00677 & 0.96644 & 0.06219 & -0.05293 & 0.98322 & 0.00677 & 0.00387 & 0.00756 & 1.35881 \\
\hline Modifiye Henderson and Pabis & 0.96764 & 0.04906 & 1.61380 & 0.04906 & 0.96960 & 0.04906 & - & 0.08372 & -0.07477 & 0.96960 & 0.04906 & 0.00701 & 0.01068 & 2.17362 \\
\hline \multicolumn{15}{|l|}{ Thompson } \\
\hline Wang and Singh & 0.99514 & 0.00734 & 1.61380 & 0.00734 & 0.99545 & 0.00147 & 0.99318 & 0.03239 & -0.02370 & 0.99545 & 0.00147 & 0.00105 & 0.00339 & 0.90380 \\
\hline Hii et al. & 0.98391 & 0.02376 & 1.61380 & 0.02376 & 0.98528 & 0.01188 & 0.91167 & 0.05826 & -0.03537 & 0.98528 & 0.01188 & 0.00339 & 0.00505 & 1.45610 \\
\hline $\begin{array}{l}\text { Simplified Fick's diffusion } \\
\text { (SFFD) }\end{array}$ & 0.96764 & 0.04906 & 1.61380 & 0.04906 & 0.96960 & 0.01227 & 0.93920 & 0.08372 & -0.07477 & 0.96960 & 0.01227 & 0.00701 & 0.01068 & 2.17362 \\
\hline Weibull & 0.98351 & 0.02426 & 1.61380 & 0.02426 & 0.98497 & 0.00485 & 0.97745 & 0.05887 & -0.05759 & 0.98497 & 0.00485 & 0.00347 & 0.00823 & 1.36552 \\
\hline Aghbashlo et al. & 0.99152 & 0.01270 & 1.61380 & 0.01270 & 0.99213 & 0.00254 & 0.98819 & 0.04260 & -0.04956 & 0.99213 & 0.00254 & 0.00181 & 0.00708 & 1.14770 \\
\hline Parabolic & 0.99526 & 0.00686 & 1.61380 & 0.00686 & 0.99575 & 0.00172 & 0.99149 & 0.03131 & 0.00000 & 0.99575 & 0.00172 & 0.00098 & 0.00000 & 0.92226 \\
\hline Balbay and Şahin & 0.99530 & 0.00681 & 1.61380 & 0.00681 & 0.99578 & 0.00227 & 0.98735 & 0.03118 & -0.00135 & 0.99578 & 0.00227 & 0.00097 & 0.00019 & 0.87227 \\
\hline $\begin{array}{l}\text { Alibas (Modifiye Midilli- } \\
\text { Kucuk) }\end{array}$ & 0.99575 & 0.00616 & 1.61380 & 0.00616 & 0.99618 & 0.00308 & 0.97709 & 0.02967 & 0.00000 & 0.99618 & 0.00308 & 0.00088 & 0.00000 & 0.75648 \\
\hline
\end{tabular}




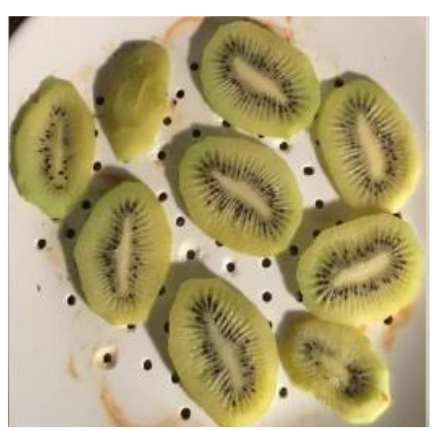

(a)

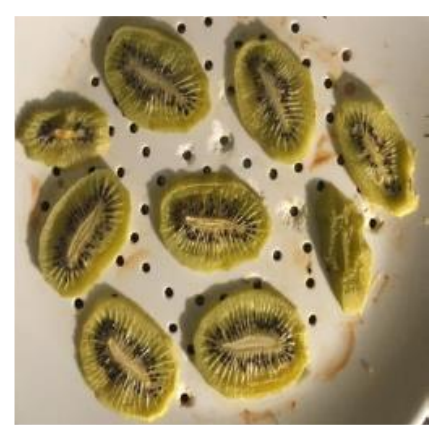

(b)

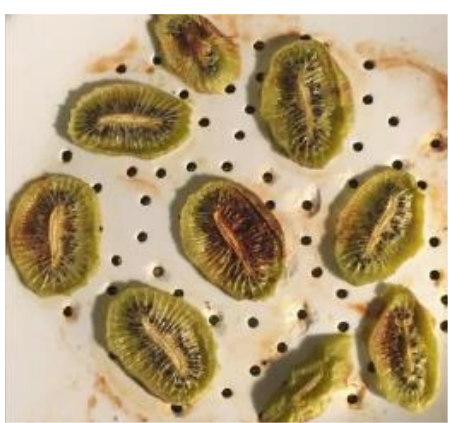

(c)

Figure 6. Photographs taken during the experiments for kiwi (a) initial stage, (b) mid stage, (c) last stage (Şimşek, 2018)

\subsection{Mint Samples}

Drying experiments of mint are done at $100 \mathrm{~W}$, $300 \mathrm{~W}, 450 \mathrm{~W}, 600 \mathrm{~W}, 700 \mathrm{~W}$ and $800 \mathrm{~W}$ microwave powers. The dimensionless mass ratios obtained for the five best model are presented in Figure 7. Also, drying curve equations for $700 \mathrm{~W}$ microwave power for which the most suitable drying is obtained for kiwi are presented in Table 6 .

Drying times are determined as 5, 8, 10, 10, 15 and 65 minutes for $800 \mathrm{~W}, 700 \mathrm{~W}, 600 \mathrm{~W}, 450 \mathrm{~W}$,
$300 \mathrm{~W}$ and $100 \mathrm{~W}$ power values, respectively. It is seen that the dimensionless mass ratio almost linearly decreases for higher microwave powers (700W, 800W) and nonlinearly decreases for lower microwave powers $(100 \mathrm{~W}, 300 \mathrm{~W}, 450 \mathrm{~W}$, $600 \mathrm{~W}$ ) with increasing of time.

The best models are obtained as Aghbashlo et al., Aghbashlo et al., Aghbashlo et al., Hii et al., Midilli-Kucuk, Aghbashlo et al. for 100W, $300 \mathrm{~W}, 450 \mathrm{~W}, 600 \mathrm{~W}, 700 \mathrm{~W}$ and $800 \mathrm{~W}$, respectively, and drying curve equations are given in Equations (58-63) for each best model.

$$
\begin{aligned}
& M R=\exp \left(-\frac{0.013633 t}{1-0.013896 t}\right) \\
& M R=\exp \left(-\frac{0.051884 t}{1-0.060599 t}\right) \\
& M R=\exp \left(-\frac{0.072717 t}{1-0.093828 t}\right) \\
& M R=0.7714 \exp \left(-0.0136 t^{2.8727}\right)+0.2285 \exp \left(-6.6419 t^{2.8727}\right) \\
& M R=0.998522 \exp \left(-0.088416 t^{1.977331}\right)-0.001532 t \\
& M R=\exp \left(-\frac{0.232215 t}{1-0.197517 t}\right)
\end{aligned}
$$



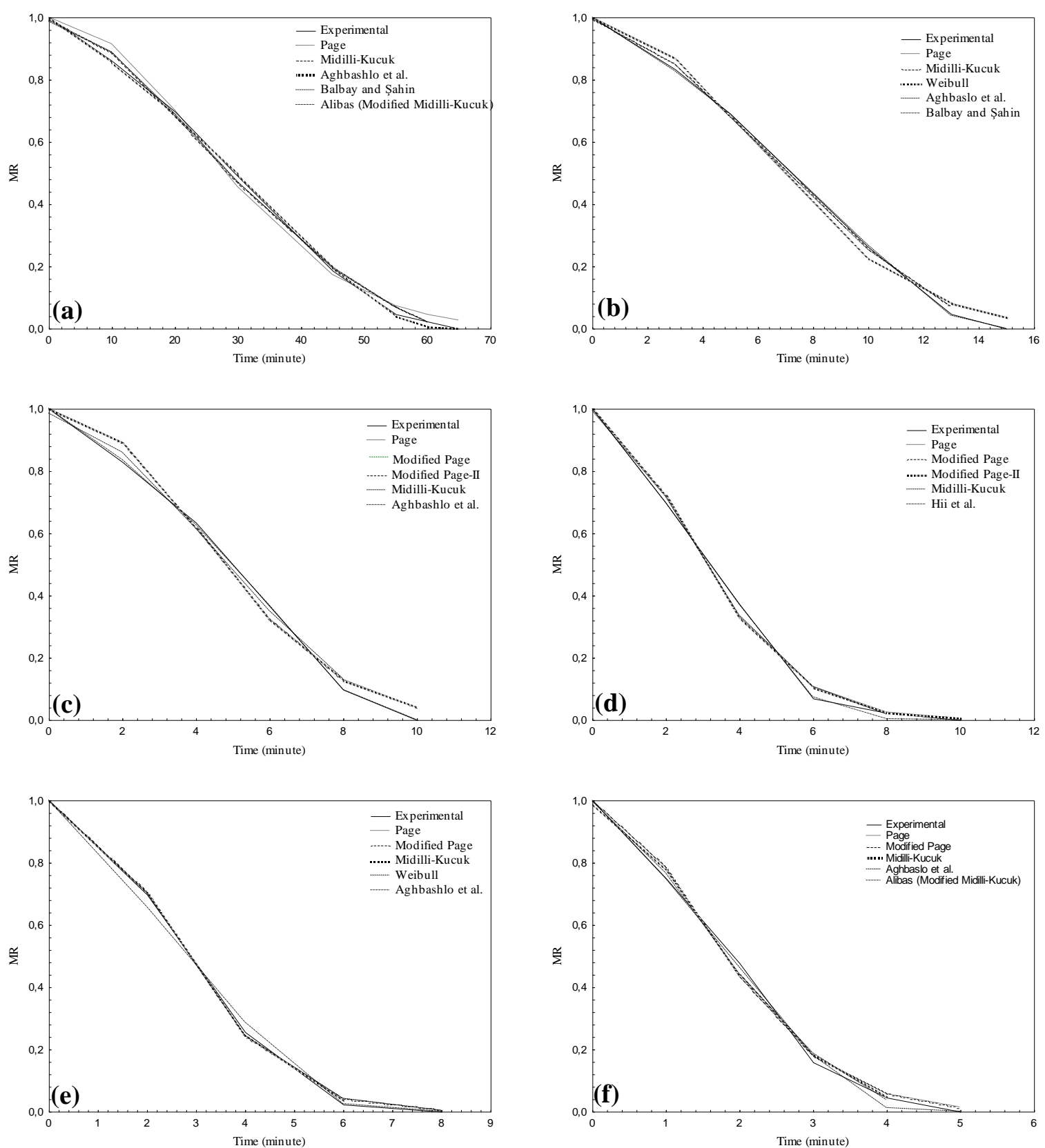

Figure 7. Variation of dimensionless mass ratio over time for mint (a) $100 \mathrm{~W}$, (b) $300 \mathrm{~W}$, (c) 450W, (d) $450 \mathrm{~W}$, (e) $600 \mathrm{~W}$, (f) $700 \mathrm{~W}$, (g) $800 \mathrm{~W}$ 
Table 6. Evaluation criteria of mint for 700W

\begin{tabular}{|c|c|c|c|c|c|c|c|c|c|c|c|c|c|c|}
\hline Model Name & $\mathrm{r}$ & RSS & SST & SSE & $\mathrm{R}^{2}$ & $\chi^{2}$ & $\bar{R}^{2}$ & RMSE & residuals & $\mathrm{EF}$ & SEE & RSSE & MBE & $\mathrm{P}$ \\
\hline Newton, Lewis & 0.97470 & 0.05072 & 0.99375 & 0.05072 & 0.94897 & 0.01268 & 0.93195 & 0.10071 & -0.05134 & 0.94897 & 0.01268 & 0.01014 & 0.01027 & 3.97392 \\
\hline Page & 0.99971 & 0.00052 & 0.99375 & 0.00052 & 0.99947 & 0.00017 & 0.99895 & 0.01023 & -0.01633 & 0.99947 & 0.00017 & 0.00010 & 0.00327 & 0.40058 \\
\hline Modified Page & 0.99971 & 0.00052 & 0.99375 & 0.00052 & 0.99947 & 0.00017 & 0.99895 & 0.01023 & -0.01633 & 0.99947 & 0.00017 & 0.00010 & 0.00327 & 0.40058 \\
\hline Modified Page-I & - & 2.59924 & 0.99375 & 2.59924 & -1.61560 & 0.86641 & -4.23119 & 0.72101 & -3.02326 & -1.61560 & 0.86641 & 0.51985 & 0.60465 & 30.58824 \\
\hline Modified Page-II & 0.99971 & 0.00052 & 0.99375 & 0.00052 & 0.99947 & 0.00026 & 0.99789 & 0.01023 & -0.01633 & 0.99947 & 0.00026 & 0.00010 & 0.00327 & 0.40058 \\
\hline Henderson and Pabis & 0.97264 & 0.04752 & 0.99375 & 0.04752 & 0.95218 & 0.01584 & 0.90436 & 0.09749 & -0.11134 & 0.95218 & 0.01584 & 0.00950 & 0.02227 & 4.29770 \\
\hline Logarithmic & 0.98697 & 0.01996 & 0.99375 & 0.01996 & 0.97991 & 0.00998 & 0.91965 & 0.06319 & 0.00000 & 0.97991 & 0.00998 & 0.00399 & 0.00000 & 3.01515 \\
\hline Midilli-Kucuk & 0.99977 & 0.00036 & 0.99375 & 0.00036 & 0.99964 & 0.00036 & - & 0.00851 & -0.00109 & 0.99964 & 0.00036 & 0.00007 & 0.00022 & 0.36837 \\
\hline Demir et al. & 0.98697 & 0.01996 & 0.99375 & 0.01996 & 0.97991 & 0.01996 & - & 0.06319 & 0.00000 & 0.97991 & 0.01996 & 0.00399 & 0.00000 & 3.01515 \\
\hline Two-Term & 0.97264 & 0.04752 & 0.99375 & 0.04752 & 0.95218 & 0.04752 & - & 0.09749 & -0.11134 & 0.95218 & 0.04752 & 0.00950 & 0.02227 & 4.29770 \\
\hline Two-Term Exponential & 0.97446 & 0.05115 & 0.99375 & 0.05115 & 0.94853 & 0.01705 & 0.89706 & 0.10114 & -0.05183 & 0.94853 & 0.01705 & 0.01023 & 0.01037 & 3.99278 \\
\hline Verma et al. & 0.98749 & 0.02014 & 0.99375 & 0.02014 & 0.97973 & 0.01007 & 0.91893 & 0.06347 & 0.03677 & 0.97973 & 0.01007 & 0.00403 & 0.00735 & 2.74790 \\
\hline Approximation of Diffusion & 0.98748 & 0.02014 & 0.99375 & 0.02014 & 0.97974 & 0.01007 & 0.91894 & 0.06346 & 0.03675 & 0.97974 & 0.01007 & 0.00403 & 0.00735 & 2.74957 \\
\hline $\begin{array}{l}\text { Modified Henderson and } \\
\text { Pabis }\end{array}$ & 0.97264 & 0.04752 & 0.99375 & 0.04752 & 0.95218 & -0.04752 & 1.09564 & 0.09749 & -0.11134 & 0.95218 & -0.04752 & 0.00950 & 0.02227 & 4.29770 \\
\hline \multicolumn{15}{|l|}{ Thompson } \\
\hline Wang and Singh & 0.99075 & 0.01570 & 0.99375 & 0.01570 & 0.98420 & 0.00523 & 0.96840 & 0.05604 & 0.04501 & 0.98420 & 0.00523 & 0.00314 & 0.00900 & 2.27704 \\
\hline Hii et al. & 0.99972 & 0.00052 & 0.99375 & 0.00052 & 0.99948 & - & 1.00209 & 0.01018 & -0.01401 & 0.99948 & - & 0.00010 & 0.00280 & 0.41894 \\
\hline $\begin{array}{l}\text { Simplified Fick's diffusion } \\
\text { (SFFD) }\end{array}$ & 0.97264 & 0.04752 & 0.99375 & 0.04752 & 0.95218 & 0.02376 & 0.80873 & 0.09749 & -0.11134 & 0.95218 & 0.02376 & 0.00950 & 0.02227 & 4.29770 \\
\hline Weibull & 0.99971 & 0.00052 & 0.99375 & 0.00052 & 0.99947 & 0.00017 & 0.99895 & 0.01023 & -0.01633 & 0.99947 & 0.00017 & 0.00010 & 0.00327 & 0.40058 \\
\hline Aghbashlo et al. & 0.99855 & 0.00251 & 0.99375 & 0.00251 & 0.99748 & 0.00084 & 0.99495 & 0.02240 & 0.00607 & 0.99748 & 0.00084 & 0.00050 & 0.00121 & 0.72738 \\
\hline Parabolic & 0.99094 & 0.01391 & 0.99375 & 0.01391 & 0.98601 & 0.00695 & 0.94402 & 0.05274 & 0.00000 & 0.98601 & 0.00695 & 0.00278 & 0.00000 & 2.42017 \\
\hline Balbay and Şahin & 0.99978 & 0.00034 & 0.99375 & 0.00034 & 0.99966 & 0.00034 & - & 0.00819 & 0.00000 & 0.99966 & 0.00034 & 0.00007 & 0.00000 & 0.35603 \\
\hline $\begin{array}{l}\text { Alibas (Modified Midilli- } \\
\text { Kucuk) }\end{array}$ & 1.00000 & 0.00000 & 0.99375 & 0.00000 & 1.00000 & - & 1.00000 & 0.00000 & 0.00000 & 1.00000 & - & 0.00000 & 0.00000 & 0.00000 \\
\hline
\end{tabular}




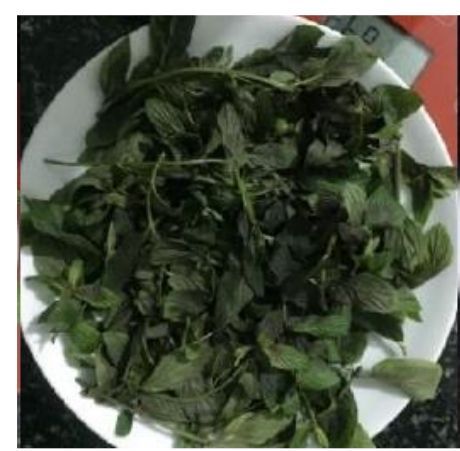

(a)

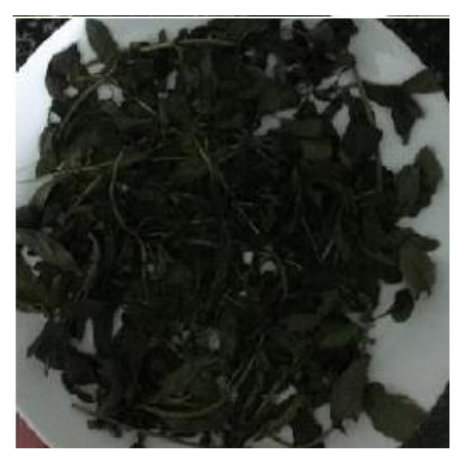

(b)

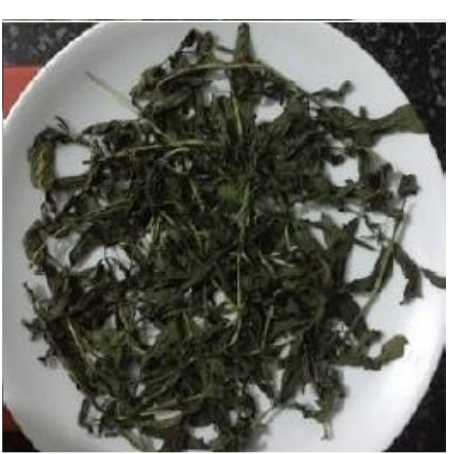

(c)

Figure 8. Photographs taken during the experiments for mint a) initial stage, (b) mid stage, (c) last stage (Şimşek, 2018)

During the drying period for $800 \mathrm{~W}, 700 \mathrm{~W}, 600 \mathrm{~W}$, $450 \mathrm{~W}, 300 \mathrm{~W}$ and $100 \mathrm{~W}$ microwave powers, it is observed that the color and shape change in the product is natural-looking and no adverse situation such as burning and redness occur (see Figure 8). The negative effects of drying apricot and kiwi with microwave are not observed in microwave drying of mint. Consequently, it is

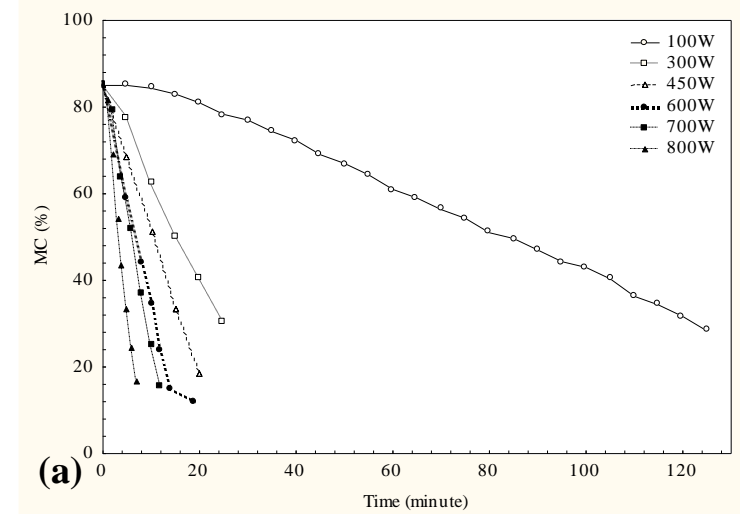

seen that drying with microwave reduces the drying time and also energy costs.

\subsection{Basic Comparison of Dried Samples}

Figures 9 (a), (b) and (c) present the variation of moisture content depending on time for apricot, kiwi and mint, respectively.

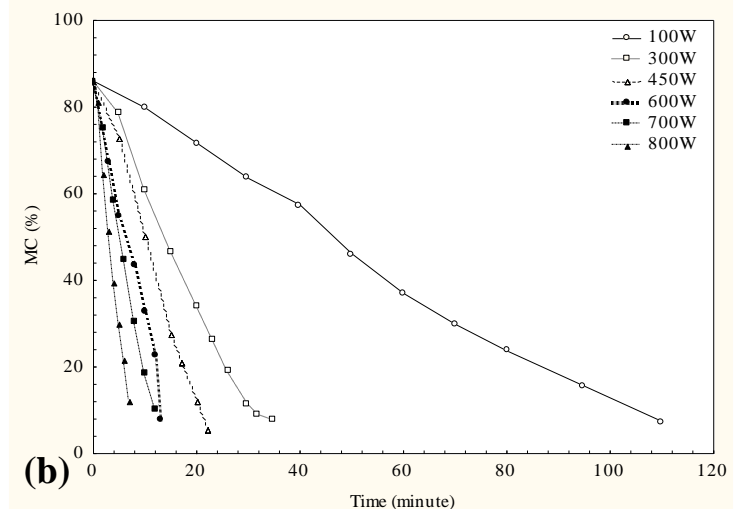

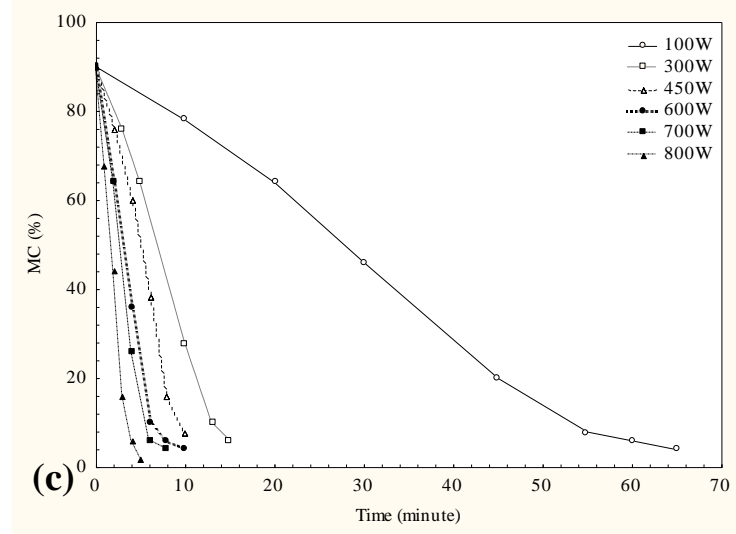

Figure 9. The variation of moisture content over time (a) apricot, (b) kiwi, (c) mint

The initial moisture content are determined as $85 \%, 86 \%$ and $90 \%$ for apricot, kiwi and mint, respectively. The moisture content almost linearly decreases with increasing of time for each product. Also, it is observed that when the microwave power rises the moisture transfer time highly decrease for each product. However, it is seen that the fastest decrease in moisture content 
occurred in mint, kiwi and apricot samples, respectively, for each microwave power.

Figures 10 (a), (b) and (c) present the variation of mass shrinkage ratio ovet time for apricot, kiwi and mint, respectively. The mass shrinkage ratio almost linearly reduces with rising of time for

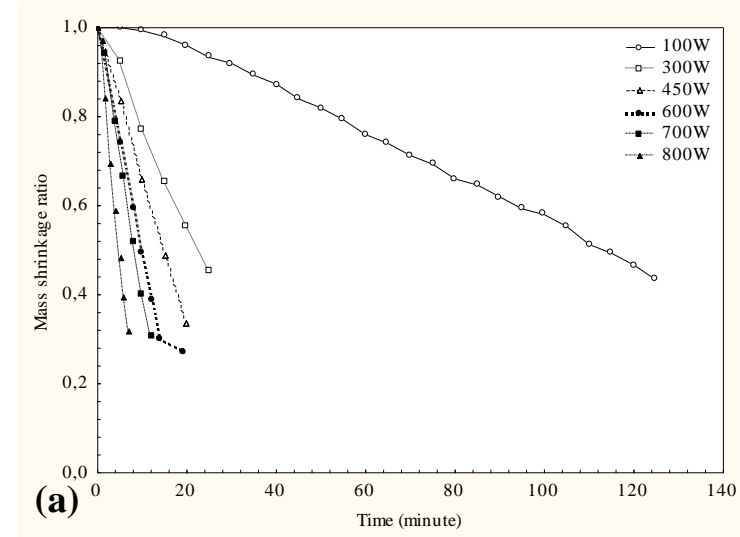

each product. Also, it is observed that when the microwave power increases the mass shrinkage ratio time highly decrease for apricot, kiwi and mint samples. Furthermore, it seems that the fastest decrease in mass shrinkage ratio occurred in mint, kiwi and apricot for each microwave power, respectively.
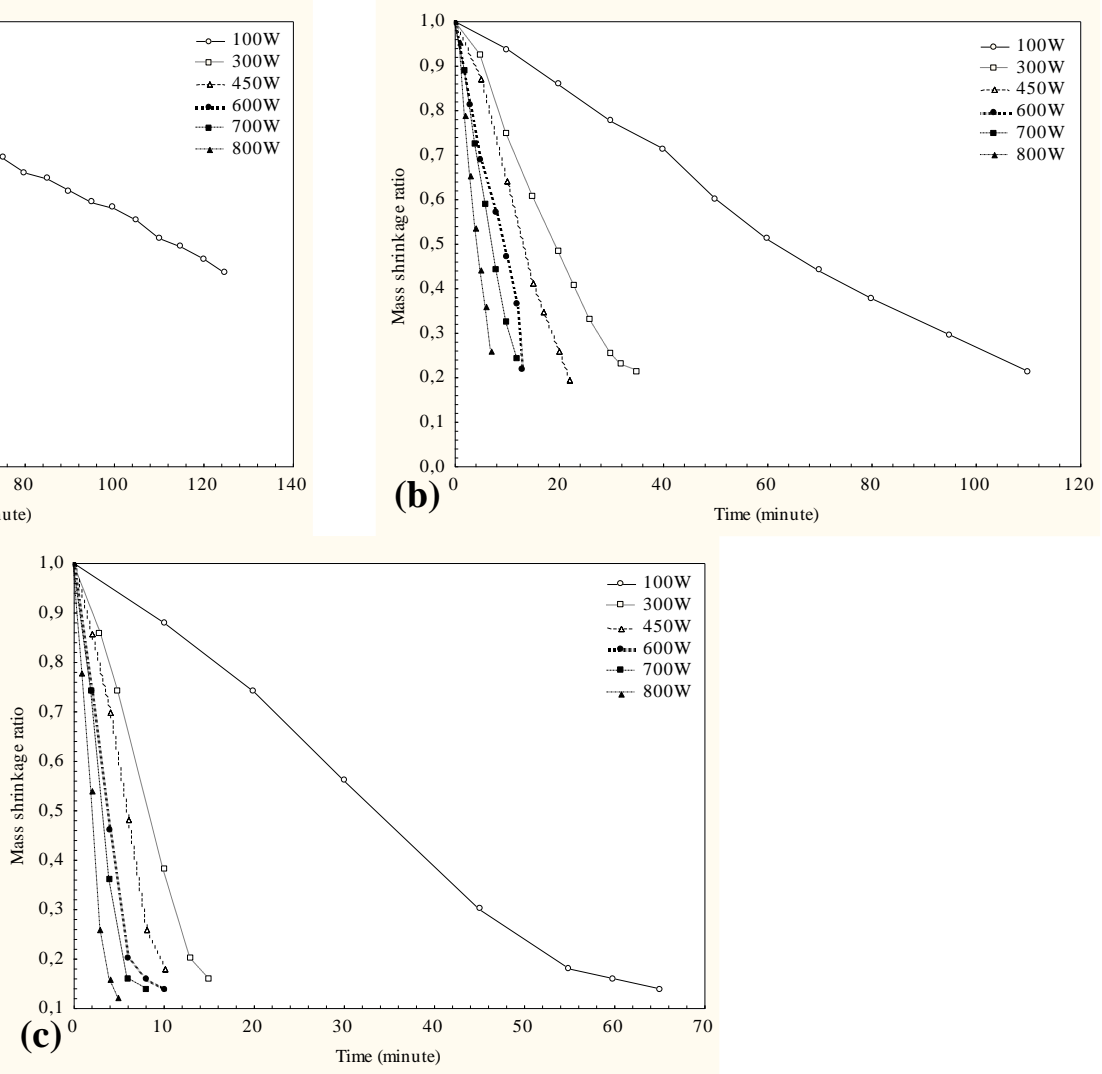

Figure 10. The variation of mass shrinkage ratio over time (a) apricot, (b) kiwi, (c) mint

Figures 11 (a), (b) and (c) present the change of drying rate over time at different microwave powers for apricots, kiwi and mint, respectively. It is observed that the drying rate increases with increasing of microwave power. Maximum drying rates of apricots estimated as 23 gwater/min at $3 \mathrm{rd}$ minute, $11.5 \mathrm{gwater} / \mathrm{min}$ at 4 th minute, 8 gwater $/ \mathrm{min}$ at 12 th minute, 5.2 gwater/min at 10-15th minute, 4.6 gwater/min at 10th minute and 1.2 gwater/min at 110th minute for $800 \mathrm{~W}, 700 \mathrm{~W}, 600 \mathrm{~W}, 450 \mathrm{~W}, 300 \mathrm{~W}$, and $100 \mathrm{~W}$, respectively. Drying times for the same power values are determined 7, 12, 19, 20, 25 and 125 minutes, respectively.

For kiwi samples maximum drying rates estimated as 14 gwater/min at $2 \mathrm{nd}$ minute, 7.5 gwater/min at 4 th minute, 14 gwater $/ \mathrm{min}$ at 13 th minute, 4.2 gwater/min at $10-15$ th minute, 2.8 gwater/min at 10th minute and 1.1 gwater/min at 50 th minute for $800 \mathrm{~W}, 700 \mathrm{~W}, 600 \mathrm{~W}, 450 \mathrm{~W}$, $300 \mathrm{~W}$, and $100 \mathrm{~W}$, respectively. Drying times for the same power values are determined 7, 12, 13, 22, 30 and 110 minutes, respectively.

Maximum drying rates of mint samples estimated as 14 gwater/min at $3 \mathrm{rd}$ minute, 9.5 gwater/min at 4th minute, 7 gwater $/ \mathrm{min}$ at 4 th minute, 5.5 gwater/min at $6-8$ th minute, 3.6 gwater $/ \mathrm{min}$ at 10th minute and 0.9 gwater/min at 30th minute for $800 \mathrm{~W}, 700 \mathrm{~W}, 600 \mathrm{~W}, 450 \mathrm{~W}, 300 \mathrm{~W}$, and $100 \mathrm{~W}$, respectively. Drying times for the same power values are determined 5, 8, 10, 10, 15 and 65 minutes, respectively. 

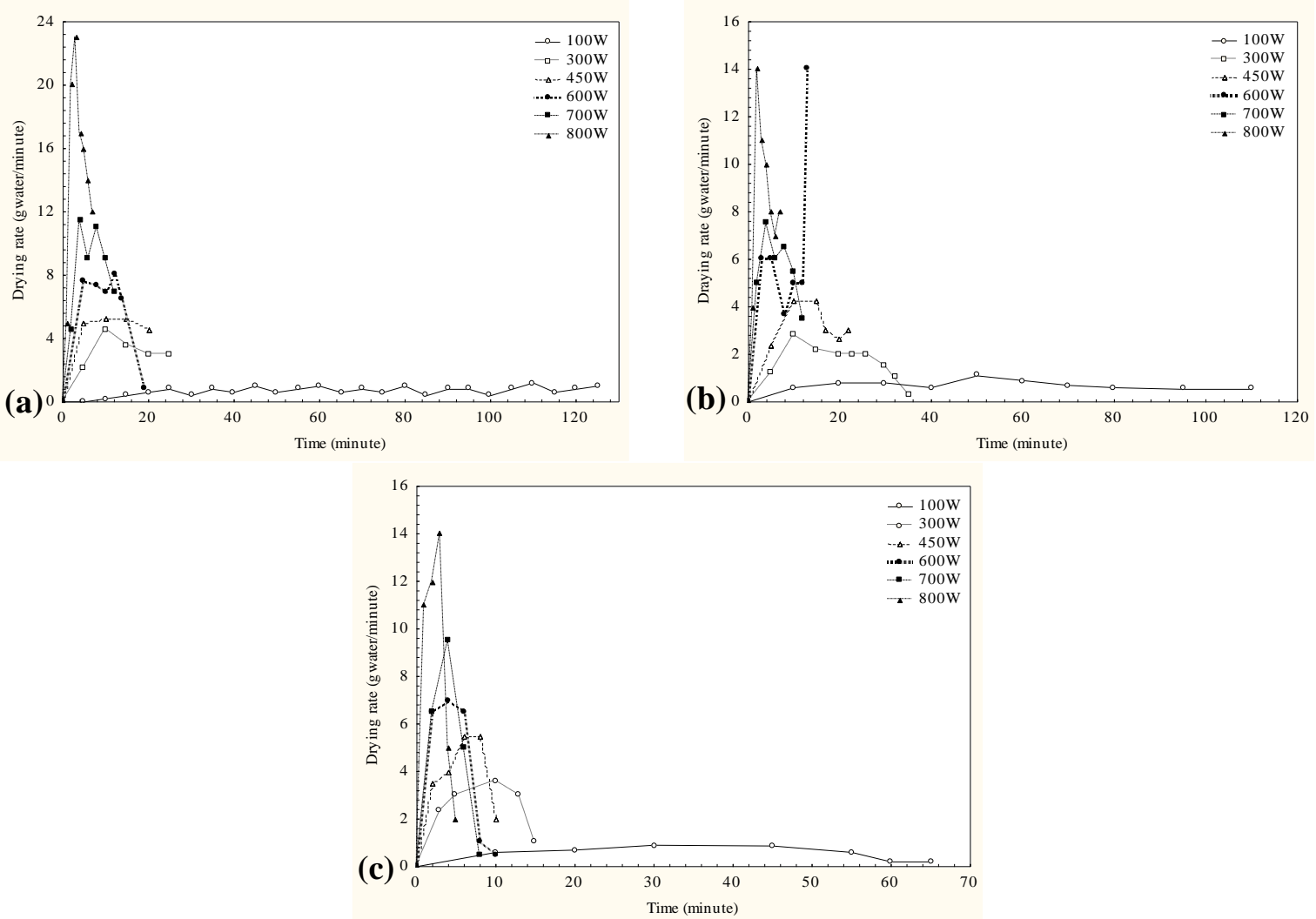

Figure 11. The variation of drying rate over time (a) apricot, (b) kiwi, (c) mint.

\section{Conclusions}

In this study, microwave drying behaviors of apricot, kiwi and mint leaves are experimentally investigated for different microwave powers (100W, 300W, 450W, 600W, $700 \mathrm{~W}$, and $800 \mathrm{~W})$. Some important concluding remarks are given as follows:

$\checkmark$ The most suitable microwave power is $300 \mathrm{~W}$ for thin layer microwave apricot drying.

$\checkmark$ The most suitable model is Modified Page model for thin layer microwave apricot drying

$\checkmark$ The most suitable microwave power is $600 \mathrm{~W}$ for thin layer microwave kivi drying.

$\checkmark$ The most suitable model is Midilli-Kucuk model for thin layer microwave kiwi drying

$\checkmark$ The most suitable microwave power is $700 \mathrm{~W}$ for thin layer microwave mint drying.

$\checkmark$ The most suitable model is Midilli-Kucuk model for thin layer microwave mint drying.

$\checkmark$ Drying time significantly decreases as microwave drying power increases.

$\checkmark$ The fastest decrease in moisture content and mass shrinkage ratio occurred in mint, kiwi and apricot for each microwave power, respectively.

$\checkmark$ Drying rate increases with increasing of microwave power for each product sample.

$\checkmark$ Microwave drying method is not suitable for drying apricots especially at high microwave powers.

\section{References}

Agbede, O.O., Oke, E.O, Akinfenwa, S.I., Wahab, K.T., Ogundipe, S., Aworanti, O.A., Arinkoola, A.O., Agarry, S.E., Ogunleye, O.O, Osuolale, F.N., Babatunde, K.A. (2020). Thin layer drying of green microalgae (Chlorella sp.) paste biomass: Drying characteristics, energy requirement and mathematical modeling. Bioresource Technology Reports, 11 , 100467. https://doi.org/10.1016/j.biteb.2020.100467

Al-Harahsheh, M., Al-Muhtaseb, A.H., Magee, T.R.A. (2009). Microwave drying kinetics of tomato pomace: effect of osmotic dehydration. Chemical Engineering and Processing: Process Intensification, $\quad 48(1), \quad$ 524-531. https://doi.org/10.1016/j.cep.2008.06.010 
Alibaş, İ. (2012). Microwave drying of grapevine (Vitis vinifera L.) leaves and determination of some quality parameters. Journal of Agricultural Sciences, 18, 43-53. In Turkish

Argyropoulos, D., Heindl, A., Müller, J. (2011). Assessment of convection, hot-air combined with microwave-vacuum and freeze-drying methods for mushrooms with regard to product quality. International Journal of Food Science and Technology, 46(2), 333-342. https://doi.org/10.1111/j.1365-2621.2010.02500.x

Balbay, A., Şahin, Ö. (2012). Microwave drying kinetics of a thin-layer liquorice root. Drying Technology, 30(8), 859-864. https://doi.org/10.1080/07373937.2012.670682

Baltacioğlu, C., Uslu, N., Özcan, M.M. (2015). Optimization of microwave and air drying conditions of quince (Cydonia oblonga, Miller) using response surface methodology. Italian Journal of Food Science, 27, 1-7. https://doi.org/10.14674/1120-1770/IJFS.V85

Bingol, G., Pan, Z., Roberts, J.S., Devres, Y.O., Balaban, M.O. (2008). Mathematical modeling of microwave-assisted convective heating and drying of grapes. International Journal of Agricultural and Biological Engineering, 1(2), 46-54. 10.3965/j.issn.1934-6344.2008.02.046-054

Chahbani, A., Fakhfakh, N., Balti, M.A., Mabrouk, M., El-Hatmid, H., Zouari, N., Kechaou, N. (2018). Microwave drying effects on drying kinetics, bioactive compounds and antioxidant activity of green peas (Pisum sativum L.). Food Bioscience, 25 , $32-38$. https://doi.org/10.1016/j.fbio.2018.07.004

Cuccurullo, G., Metallo, A., Corona, O., Cinquanta, L. (2019). Comparing different processing methods in apple slice drying. Part 1. Performance of microwave, hot air and hybrid methods at constant temperatures. Biosystems Engineering, 188, 331344.https://doi.org/10.1016/j.biosystemseng.2019. 10.021

Dadali, G., Demirhan, E., Özbek, B. (2007). Microwave heat treatment of spinach: drying kinetics and effective moisture diffusivity. Drying Technology, 25(10), 1703-1712. https://doi.org/10.1080/07373930701590954

Dadali, G., Özbek, B. (2008). Microwave heat treatment of leek: Drying kinetic and effective moisture diffusivity. International Journal of Food
Science and Technology, 43(8), 1443-1451. https://doi.org/10.1111/j.1365-2621.2007.01688.x

Darvishi, H. (2012). Energy consumption and mathematical modeling of microwave drying of potato slices. Agricultural Engineering International: CIGR Journal, 4(1), 94-102.

Darvishi, H., Azadbakht, M., Rezaeias, A., Farhang, A. (2013). Drying characteristics of sardine fish dried with microwave heating. Journal of the Saudi Society of Agricultural Sciences, 12(2), 121-127. https://doi.org/10.1016/j.jssas.2012.09.002

Demirhan, E., Özbek, B. (2010a). Microwave-drying characteristics of basil. Journal of Food Processing and Preservation, 34(3), 476-494. https://doi.org/10.1111/j.1745-4549.2008.00352.x

Demirhan, E., Özbek, B. (2010b). Drying kinetics and effective moisture diffusivity of purslane undergoing microwave heat treatment. Korean Journal of Chemical Engineering, 27(5), 13771383. https://doi.org/10.1007/s11814-010-0251-2

Demirhan, E., Ozbek, B. (2011). Thin-layer drying characteristics and modeling of celery leaves undergoing microwave treatment. Chemical Engineering Communications, 198(7), 957-975. https://doi.org/10.1080/00986445.2011.545298

Doğru, M., Midilli, A., Howarth C.R. (2002). Gasification of sewage sludge using a throated downdraft gasifier and uncertainty analysis. Fuel Processing Technology 75, 55-82. https://doi.org/10.1016/S0378-3820(01)00234-X

Drouzas, A.E., Tsami, E. and Saravacos, G.D. (1999). Microwave-vacuum drying of model fruit gels. Journal of Food Engineering, 39(2), 117-122. https://doi.org/10.1016/S0260-8774(98)00133-2

Du, J., Gao, L., Yang, Y., Guo, S., Chen, J., Omran, M., Chen, G. (2020). Modeling and kinetics study of microwave heat drying of low grade manganese ore. Advanced Powder Technology, 31, 2901-2911. https://doi.org/10.1016/j.apt.2020.05.013

Duan, Z., Zhang, M., Hu, Q., Sun, J. (2005). Characteristics of microwave drying of bighead carp. Drying Technology, 23(3), 637-643.

Eştürk, O., Soysal, Y. (2010). Drying properties and quality parameters of dill dried with intermittent and continuous microwave-convective air treatments, Journal of Agricultural Sciences, 16, 26-36.

https://doi.org/10.1501/Tarimbil_0000001118 
Esturk, O. (2012). Intermittent and continuous microwave-convective air-drying characteristics of sage (Salvia officinalis) leaves. Food and Bioprocess Technology, 5(5), 1664-1673. https://doi.org/10.1007/s11947-010-0462-x

Evin, D. (2011). Investigation on the drying kinetics of sliced and whole rosehips at different moisture contents under microwave treatment. Scientific Research and Esssays, 6(11), 2337-2347. https://doi.org/10.5897/SRE11.082

Fu, B.A., Chen, M.Q, Song, J.J. (2017). Investigation on the microwave drying kinetics and pumping phenomenon of lignite spheres. Applied Thermal Engineering, 371-380. https://doi.org/10.1016/j.applthermaleng.2017.06. 034

Ganesapillai, M., Regupathi, I., Murugesan, T. (2008). An empirical model for the estimation of moisture ratio during microwave drying of plaster of paris. Drying Technology, 26(7), 963-978. https://doi.org/10.1080/07373930802142978

Ganesapillai, M., Miranda, L.R., Regupathi, I. (2009). Mathematical modeling in drying and determination of effective moisture diffusivity of caso41/2h2o during microwave drying. In Proceedings of First International Conference on Nanostructured Materials and Nanocomposites, April 6-8, 373-381, Kottayam, India.

Ganesapillai, M., Regupathi, I., Murugesan, T. (2011). Modeling of thin layer drying of banana (Nendran Spp) under microwave, convective and combined microwave-convective processes. Chemical Product and Process Modeling, 6((1)10), 1-29. https://doi.org/10.2202/1934-2659.1479

Gunasekaran, S. (1999). Pulsed microwave-vacuum drying of food materials. Drying Technology, 17, $395-412$

https://doi.org/10.1080/07373939908917542

Hemis, M., Singh, C.B., Jayas, D. S. (2011). Microwave-sssisted thin layer drying of wheat. Drying Technology, 29, 1240-1247. https://doi.org/10.1080/07373937.2011.584999

Inyang, U.E., Oboh, I.O., Etuk, B.R. (2018). Kinetic models for drying techniques-Food materials. Advances in Chemical Engineering and Science, $8(2), 27-48$.

Karaaslan, S. (2008). The Experiments on Vegetables and Industrial Plant Drying by Microwave Energy.
Ph.D. thesis, Çukurova University, Adana, Turkey, [in Turkish].

Karaaslan, S.N., Tuncer, İ.K. (2008). Development of a drying model for combined microwave-fan assisted convection drying of spinach. Biosystems Enginering, 100, 44-52.

Karaaslan, S., Tunçer, İ.K. (2011). Development of drying model and determination of color characteristics for combined microwave-fan assisted convection drying of green tea. The Philippine Agricultural Scientist, 94(2), 161-170.

Kucuk, H., Midilli, A., Kilic, A., Dincer, I. (2014). A review on thin-layer drying-curve equations, Drying Technology, 32 (7), 757-773. https://doi.org/10.1080/07373937.2013.873047

Lekachaiworakul, P., Dangvilailux, P., Rattanamechaiskul, C. (2017). Effects of hot air and microwave drying on kinetic rate and mechanical property of oil palm veneer. Energy Procedia, 138, 1093-1098.

Li, H., Lin, B,, Hong, Y., Liu, T., Huang, Z., Wang, R., Wang, Z. (2018). Assessing the moisture migration during microwave drying of coal using low-field nuclear magnetic resonance. Drying Technology, 36(5), 567-577. https://doi.org/10.1080/07373937.2017.1349136

Lopez-Vidana, E.C., Figueroa,I.P., Cortes, F.B., Rojano, B.A., Ocaana, A.N. (2017). Effect of temperature on antioxidant capacity during drying process of mortiño (Vaccinium meridionale Swartz). International Journal of Food Properties, 20(2), 294-305.

Maskan, M. (2001). Drying, shrinkage and dehydration characteristics of kiwifruits during hot air and microwave drying. Journal of Food Engineering, 48, 177-182. https://doi.org/10.1016/S02608774(00)00155-2

McMinn, W.A.M., McLoughlin, C.M., Magee, T.R.A. (2005). Thin-layer modeling of microwave, microwave-convective, and microwave-vacuum drying of pharmaceutical powders. Drying Technology, 23(3), 513-532. https://doi.org/10.1081/DRT-200054126

McMinn, W.A.M. (2006). Thin-layer modeling of the convective, microwave, microwave-convective and microwave-vacuum drying of lactose powder. Journal of Food Engineering, 72(2), 113-123. https://doi.org/10.1016/j.jfoodeng.2004.11.025 
Midilli A., Olgun H., Ayhan T. (1999). Experimental studies on mushroom and pollen drying. International Journal of Energy Research, 23, 1143-1152. https://doi.org/10.1002/(SICI)1099114X(19991025)23:13<1143::AID-

ER544>3.0.CO;2-3

Motevali, A., Minaei, S., Banakar, A., Ghobadian, B., Darvishi, H. (2016). Energy analyses and drying kinetics of chamomile leaves in microwaveconvective dryer. Journal of the Saudi Society of Agricultural Sciences, 15, 179-187. https://doi.org/10.1016/j.jssas.2014.11.003

Murthy, T.P.K., Manohar, B. (2012). Microwave drying of mango ginger (Curcuma amada Roxb): Prediction of drying kinetics by mathematical modelling and artificial neural network. International Journal of Food Science and Technology, 47(6), 1229-1236. https://doi.org/10.1111/j.1365-2621.2012.02963.x

Nair, G.R., Liplap, P., Gariepy, Y., Raghavan, G.S.V. (2011). Microwave drying of flax fibre at controlled temperatures. Journal of Agricultural Science and Technology B, 1(8b), 1103-1115. https://doi.org/10.1504/IJPTI.2012.050982

Nindo, C.I., Sun, T., Wang, S.W., Tang, J., Powers, J.R. (2003). Evaluation of drying technologies for retention of physical quality and antioxidants in asparagus (Asparagus officinalis L.). Lebensmittel Wissenschaft und Technologie, 36, 507-515. https://doi.org/10.1016/S0023-6438(03)00046-X

Özbek, B., Dadali, G. (2007). Thin layer drying characteristics and modeling of mint leaves undergoing microwave treatment. Journal of Food Engineering, 83(4), 541-549. https://doi.org/10.1016/j.jfoodeng.2007.04.004

Özkan, İ., Akbudak, A., Akbudak, N. (2007). Microwave drying characteristics of spinach. Journal of Food Engineering, 78(2), 577-583. https://doi.org/10.1016/j.jfoodeng.2005.10.026.

Pillai, M.G., Regupathi, I., Miranda, L.R.,Murugesan, T. (2010). Moisture diffusivity and energy consumption during microwave drying of plaster of paris. Chemical Product and Process Modeling, $5(1), \quad 4, \quad 1-23$. http://www.bepress.com/cppm/vol5/iss1/4.

Qiu, L., Zhang, M., Tang, J., Adhikari, B., Cao, P. (2019). Innovative technologies for producing and preserving intermediate moisture foods: A review.
Food Research International, 116, 90-102. https://doi.org/10.1016/j.foodres.2018.12.055.

Ranjbaran, M., Zare, D. (2012). A new approach for modeling of hot air-microwave thin layer drying of soybean. Electronic Journal of Polish Agricultural Universities, 15(3), 795-810.

Reddy, L. (2006). Drying Characteristics of Saskatoon Berries under Microwave and Combined Microwave-convection Heating. M.Sc. thesis, University of Saskatchewan, Saskatoon, Canada.

Sarimeseli, A. (2011). Microwave drying characteristics of coriander (Coriandrum sativum L.) leaves. Energy Conversion and Management, 52(2), 1449-1453.

Shah, S., Joshi, M. (2010). Modeling microwave drying kinetics of sugarcane bagasse. International Journal of Electronics Engineering, 2(1), 159-163.

Sharifian, F., Motlagh, A.M., Nikbakht, A.M. (2012). Pulsed microwave drying kinetics of fig fruit (Ficus carica L.). Australian Journal of Crop Science, 6(10), 1441-1447.

Shen, L., Zhu, Y., Liu, C., Wang, L., Liu, H., Kamruzzaman, M., Liu, C., Zhang, Y., Zheng, X. (2020). Modelling of moving drying process and analysis of drying characteristics for germinated brown rice under continuous microwave drying. Biosystems Engineering, 195, $6 \quad 4-8 \quad 8$. https://doi.org/10.1016/j.biosystemseng.2020.05.0 02

Silva, F.A., Marsaioli Jr.A., Maximo,G.J., Silva, M.A.A.P., And Gonçalves, L.A.G. (2006). Microwave assisted drying of macadamia nuts. Journal of Food Engineering, (77), 550-558.

Sledz, M., Witrowa-Rajchert, D. (2012). Kinetics of microwave-convective drying of some herbs. International Conference of Agricultural Engineering, July 8-12, Valencia, Spain.

Soysal, Y., Öztekin, S., Eren, Ö. (2006). Microwave drying of parsley: Modelling, kinetics, and energy aspects. Biosystems Engineering, 93(4), 403-413. https://doi.org/10.1016/j.biosystemseng.2006.01.0 17

Szadzinska, J., Kowalski, S.J., Stasiak, M. (2016). Microwave and ultrasound enhancement of convective drying of strawberries: Experimental and modeling efficiency. International Journal of Heat and Mass Transfer, 103, 1065-1074. 
https://doi.org/10.1016/j.ijheatmasstransfer.2016.0 8.001

Şimşek, M. (2018). Experimental investigation and mathematical modeling of microwave drying behavior of some vegetables and fruits. M.Sc. Thesis, Recep Tayyip Erdogan University, Rize, Turkey.

Thiagarajan, I.V. (2008). Combined Microwaveconvection Drying and Textural Characteristics of Beef Jerky. M.Sc. thesis, University of Saskatchewan, Saskatoon, Canada.

Venkatesh, M.S., Raghavan, G.S.V. (2004). An overview of microwave processing and dielectric properties of agri-food materials. Biosystem Engineering, 88(1), 1-18. https://doi.org/10.1016/j.biosystemseng.2004.01.0 07

Wang, S., Tang, J., Johnson, J.A., Mitcham, E. J., Hansen, D., Hallman, G., Drake, S.R., Wang, Y. (2003). Dielectric properties of fruits and insect pests as related to radio frequency and microwave treatments. Biosystem Engineering, 85, 201-212. https://doi.org/10.1016/S1537-5110(03)00042-4

Wang, Z.-F., Fang, S.-Z., Hu, X.-S. (2009). Effective diffusivities and energy consumption of whole fruit

\section{Nomenclature}

$\mathrm{a}, \mathrm{b}, \mathrm{c}, \mathrm{g}$
$\mathrm{c}, \mathrm{g}, \mathrm{h}, \mathrm{k}, \mathrm{k}_{0}, \mathrm{k}_{1}, \mathrm{k}_{2}$
DR
EF
MBE
MC
MR
$\mathrm{S}_{\mathrm{mr}}$
$\mathrm{M}_{\mathrm{t}}$

\section{$\mathrm{M}_{\mathrm{t}+\mathrm{dt}}$}

$\mathrm{M}_{\mathrm{i}}$

$\mathrm{M}_{\mathrm{e}}$

$\mathrm{N}$
$\mathrm{n}$
$\mathrm{P}$
$\mathrm{r}$
$\mathrm{R}^{2}$

Empirical constants in models

Drying constants $\left(\mathrm{min}^{-1}\right)$

Drying rate (g water/minute)

Modeling efficiency

Mean bias error

Moisture content

Dimensionless mass ratio

Mass shrinkage ratio

Product moisture on dry basis at "t" (g water/g dry solid

Product moisture on dry basis at " $\mathrm{t}+\mathrm{dt}$ " (g water/g dry solid

Initial product moisture on dry basis (g water/g dry solid)

Equilibrium or final product moisture on dry basis (g water/g dry solid)

Number of observations

Number of constants

Mean relative percentage

error

Correlation coefficient

Coefficient of determination

Chinese jujube (Zizyphus jujuba Miller) in microwave drying. Drying Technology, 27, 10971104. https://doi.org/10.1080/07373930903221200

Won, K.H., Jonathan, C., Kim, H.E. (2004). Hydroxyapatite and gelatin composite foams processed via novel freeze-drying and crosslinking for use as temporary hard tissue scaffolds. Journal of Biocemical Resaerch, 72, 136-45. https://doi.org/10.1002/jbm.a.30168

Xu, W., Cao, X., Zhu, G., Xia, Z., Wang, D. (2020). Effect of temperature difference on the aroma and quality of carrots processed through microwave drying combined with hot air drying. Food and Bioproducts Processing, 120, 58-68. https://doi.org/10.1016/j.fbp.2019.12.006

Yurtsever, S. (2005). Mathematical modeling and evaluation of microwave drying kinetics of mint (Mentha spicatta L.). Journal of Applied Sciences, 5(7), 1266-1274. 10.3923/jas.2005.1266.1274

Zarein, M., Samadib, S.H., Ghobadian, B. (2015). Investigation of microwave dryer effect on energy efficiency during drying of apple slices. Journal of the Saudi Society of Agricultural Sciences, 14(1), 41-47. https://doi.org/10.1016/j.jssas.2013.06.002

\begin{tabular}{|c|c|}
\hline $\bar{R}^{2}$ & Adjusted $\mathrm{R}^{2}$ \\
\hline RMSE & Root mean square error \\
\hline RSS & Residual sum of squares \\
\hline RSSE & Reduced sum square error \\
\hline SEE & Standard error of estimate \\
\hline SST & Total sum of squares \\
\hline $\mathrm{t}$ & Time (minute) \\
\hline $\mathrm{W}_{\mathrm{R}}$ & Total error \\
\hline$x_{1}, x_{2}, x_{3}, \ldots, x_{n}$ & $\begin{array}{l}\text { Variables affecting } \\
\text { measurement }\end{array}$ \\
\hline $\mathrm{w}_{1}, \mathrm{w}_{2}, \mathrm{w}_{3}, \ldots, \mathrm{w}_{\mathrm{n}}$ & $\begin{array}{l}\text { Error rate related } \\
\text { independent variables }\end{array}$ \\
\hline Greek symbols & \\
\hline $\begin{array}{l}\chi^{2} \\
\text { Subscripts }\end{array}$ & Reduced chi-square \\
\hline avg & Average \\
\hline $\exp$ & Experimental \\
\hline pre & Predicted \\
\hline
\end{tabular}

